\title{
Effects of shear stress and hard clams on seston, microphytobenthos, and nitrogen dynamics in mesocosms with tidal resuspension
}

\author{
Elka T. Porter ${ }^{1, *}$, Robert P. Mason $^{2}{ }^{\text {, Lawrence P. Sanford }}{ }^{3}$ \\ ${ }^{1}$ Biology Department, Washington College, 300 Washington Ave, Chestertown, Maryland 21620, USA \\ ${ }^{2}$ Department of Marine Sciences, University of Connecticut, 1080 Shennecosset Road, Groton, Connecticut 06340, USA \\ ${ }^{3}$ Horn Point Laboratory, University of Maryland Center for Environmental Science, 2020 Horns Point Road, Cambridge, \\ Maryland 21613, USA
}

\begin{abstract}
To test the interacting effects of hard clams Mercenaria mercenaria and bottom shear stress on nutrient- and ecosystem dynamics, we performed a 4 wk experiment in six $1000 \mathrm{l}$ shear turbulence resuspension mesocosms (STURM). Three tanks each contained 50 hard clams (RC set-up), and 3 tanks had no clams (R set-up). All tanks contained defaunated muddy sediment and estuarine water and had similar water column turbulence intensities $\left(\sim 1 \mathrm{~cm} \mathrm{~s}^{-1}\right)$, energy dissipation rates $\left(\sim 0.08 \mathrm{~cm}^{2} \mathrm{~s}^{-3}\right)$, and tidal cycles ( $4 \mathrm{~h}$ mixing on and $2 \mathrm{~h}$ off). The same high instantaneous bottom stress $(0.35$ to $0.4 \mathrm{~Pa}$ ) was applied to all tanks during the mixing-on cycles. Hard clams in interaction with high bottom shear stress initially destabilized the sediments and increased seston levels to $\sim 200 \mathrm{mg} \mathrm{l}^{-1}$ in the RC tanks during the mixing-on cycles. Over time, seston concentrations declined in the RC tanks until they reached levels similar to the $\mathrm{R}$ tanks of $\sim 60 \mathrm{mg} \mathrm{l}^{-1}$. Bivalve feeding in the RC tanks significantly reduced phytoplankton biomass and shifted the phytoplankton community structure to Chlorophyceae/Prasinophytes. Nutrient (particulate phosphorus, nitrogen, and carbon, dissolved inorganic nitrogen, nitrate + nitrite, phosphate) concentrations were significantly enhanced in the RC tanks, mediated by high sediment resuspension and bivalve excretion. A brown tide organism, Aureococcus anophagefferens, bloomed in 2 of 3 RC tanks. Bivalve feeding and light limitation reduced microphytobenthos biomass in the RC tanks. Microphytobenthos biomass was low overall but significantly higher in the R tanks. Phytoplankton abundance, microphytobenthos biomass, seston concentrations, and nitrogen dynamics were significantly affected by interactions between hard clams and bottom shear stress.
\end{abstract}

KEY WORDS: Mercenaria mercenaria $\cdot$ Bivalve $\cdot$ Bottom shear - Experimental ecosystem STURM $\cdot$ Destabilization $\cdot$ Benthic flux $\cdot$ Scaling

\section{INTRODUCTION}

The commercially and ecologically important hard clam Mercenaria mercenaria (L.) is a suspension feeder abundant in shallow estuarine, and often turbid, waters on the east coast of North America (Stanley 1985, Bricelj et al. 1984). In these shallow habitats, tides, waves, and storms produce benthic shear-induced sediment resuspension at variable time scales that cause high turbidity (Schoellhamer 2002) with temporal changes in seston quantity and quality (Fegley et al. 1992, Prins et al. 1996). Mediated by changes in bottom shear stress, sediments are resuspended at different magnitudes and frequencies (Wright et al. 1997). Resuspension in low to moderately energetic tidal estuaries causes seston concentrations from $40 \mathrm{mg} \mathrm{l}^{-1}$ (Northern Chesapeake Bay; Sanford et al. 1991) to hundreds of $\mathrm{mg} \mathrm{l}^{-1}$, e.g. 
$300 \mathrm{mg} \mathrm{l}^{-1}$ during storms in Tampa Bay (Schoellhamer 1995), $600 \mathrm{mg} \mathrm{l}^{-1}$ in the Hudson River (Heyes et al. 2004), and $1500 \mathrm{mg} \mathrm{l}^{-1}$ in San Francisco Bay (Schoellhamer 2002).

The critical erosional shear stress and subsequent resuspension are mediated by the sediment bed properties and are affected by the water flow and the organisms present (Davis 1993), and the bed properties can change over time. Macrofauna change sediment erodibility through adhesive-cohesive bonding among particles (Blanchard et al. 1997) and by influencing the sediment water content, which indirectly affects the critical shear stress for resuspension (Aberle et al. 2004). In addition, bio-resuspension directly affects sediment erodibility (Davis 1993). Polychaetes and amphipods alter the sediment water content and enhance or decrease sediment stability through the type and composition of their burrow structures (Meadows \& Tait 1989), and the mucus secreted by organisms influences sediment cohesiveness (Blanchard et al. 1997) and thus sediment erodibility. The density of certain organisms, such as infaunal clams, has been shown to increase sediment erodibility in short-term flume experiments (Willows et al. 1998). The hard clam Mercenaria mercenaria can be abundant, with, for example, up to 400 ind. $\mathrm{m}^{-2}$ in a California lagoon (Murphy \& Kremer 1985) or exceeding 60 ind. $\mathrm{m}^{-2}$ in the Providence River area (Saila et al. 1966 as cited by Doering et al. 1986).

Webs of cyanobacteria or polysaccharide matrices caused by diatom movements can stabilize sediment and reduce resuspension (Yallop et al. 1994). However, microphytobenthos can also destabilize sediment as the mat ages and bubbles form within the mat, rendering the mat more erodible (Porter et al. 2004 b). In ecosystems, microphytobenthic biomass is mediated by both the light that reaches the bottom and bottom shear (MacIntyre et al. 1996, Porter et al. $2004 a, b)$ as sediment resuspension affects light transmission to the sediment surface (Porter et al. 2010). Microphytobenthos can also reduce nutrient regeneration from the sediments (Sundbäck et al. 2000) and are eaten by macrofaunal filter and deposit feeders (Muschenheim \& Newell 1992, Herman et al. 2000).

Bivalve suspension-feeders have been the subject of numerous studies and much management interest due to their ability to filter particles and clear the water column. There are numerous examples that show that bivalve suspension feeders reduce phytoplankton concentrations. For example, in previous mesocosm experiments, bivalve feeding resulted in lower phytoplankton biomass, higher light penetra- tion through the water column and higher light levels at the sediment-water interface (Porter et al. 2004a,b) and enhanced microphytobenthos growth. In the present study, we examine the interplay between shear stresses above the sediment resuspension threshold and Mercenaria mercenaria and examine the effects on the ecosystem and on water quality. We address the following specific questions and hypotheses:

(1) How does a high density of hard clams and high bottom shear stress affect phytoplankton abundance and diversity in whole ecosystem experiments? Hypothesis 1: Hard clams decrease phytoplankton abundance and affect phytoplankton diversity despite high total suspended solid concentrations.

(2) How do hard clams and high bottom shear stress affect nutrient dynamics and the nitrogen budget in an ecosystem experiment? Hypothesis 2: Hard clams in combination with high shear stress do not affect the nitrogen dynamics.

(3) How do hard clams and high bottom shear stress affect microphytobenthos abundance in whole ecosystem experiments? Hypothesis 3. Hard clams and high bottom shear stress decrease microphytobenthos abundance due to both feeding and light limitation.

\section{MATERIALS AND METHODS}

\section{Physical and biological scaling in the experimental ecosystems}

We set up 6 cylindrical shear turbulence resuspension mesocosms (STURM) tanks, with 3 tanks containing 50 hard clams (RC) each and 3 tanks containing 0 hard clams (R). We measured the physical, chemical, and biological responses to high bottom shear stress and hard clams and calculated a nitrogen budget. The STURM tanks contained a single paddle that produced high instantaneous bottom shear stress to resuspend sediments and had realistic water column turbulence levels, without overmixing the water column. The STURM tanks are the successor design of large linked mesocosms reported by Porter et al. (2004a,b) and are further described by Sanford et al. (2009), Mason \& Porter (2009) and Schneider et al. (2007; there called STORM tanks).

The paddle moved at $12.5 \mathrm{rpm}$ with a forwardstop-backward-stop motion (9 s, $1.5 \mathrm{~s}$ stop, $8 \mathrm{~s}, 1.5 \mathrm{~s}$ stop) to avoid plug flow during the mixing 'on' phase. Mixing was $4 \mathrm{~h}$ on: $2 \mathrm{~h}$ off in all systems to simulate tidal cycles throughout a 4 wk experiment. The 
$1000 \mathrm{l}$ tanks were $1 \mathrm{~m}$ deep and had a $10 \mathrm{~cm}$ layer of muddy sediment.

Direct flow and turbulence (turbulence intensities and energy dissipation rates) were measured using an acoustic Doppler velocimeter (ADV) at predefined locations throughout the tank and at different mixing speeds. Turbulence intensity, as defined by Porter et al. (2010), and energy dissipation rates were determined following Sanford (1997). Volume-weighted average turbulence intensities as determined using
Surfer (Golden Software) were $\sim 1.08 \mathrm{~cm} \mathrm{~s}^{-1}$ (Fig. 1a,b), and volume weighted energy dissipation rates were $\sim 0.08 \mathrm{~cm}^{2} \mathrm{~s}^{-3}$ during mixing (Fig. 1c,d). Turbulence intensities were similar to previous experiments (Petersen et al. 1998, Porter et al. 2004a,b, 2010) and are typical of turbulence intensities in microtidal estuaries and continental shelf bottom boundary layers (Sanford 1997 and references cited therein). This mixing setting kept energy dissipation rates from being unrealistically high.
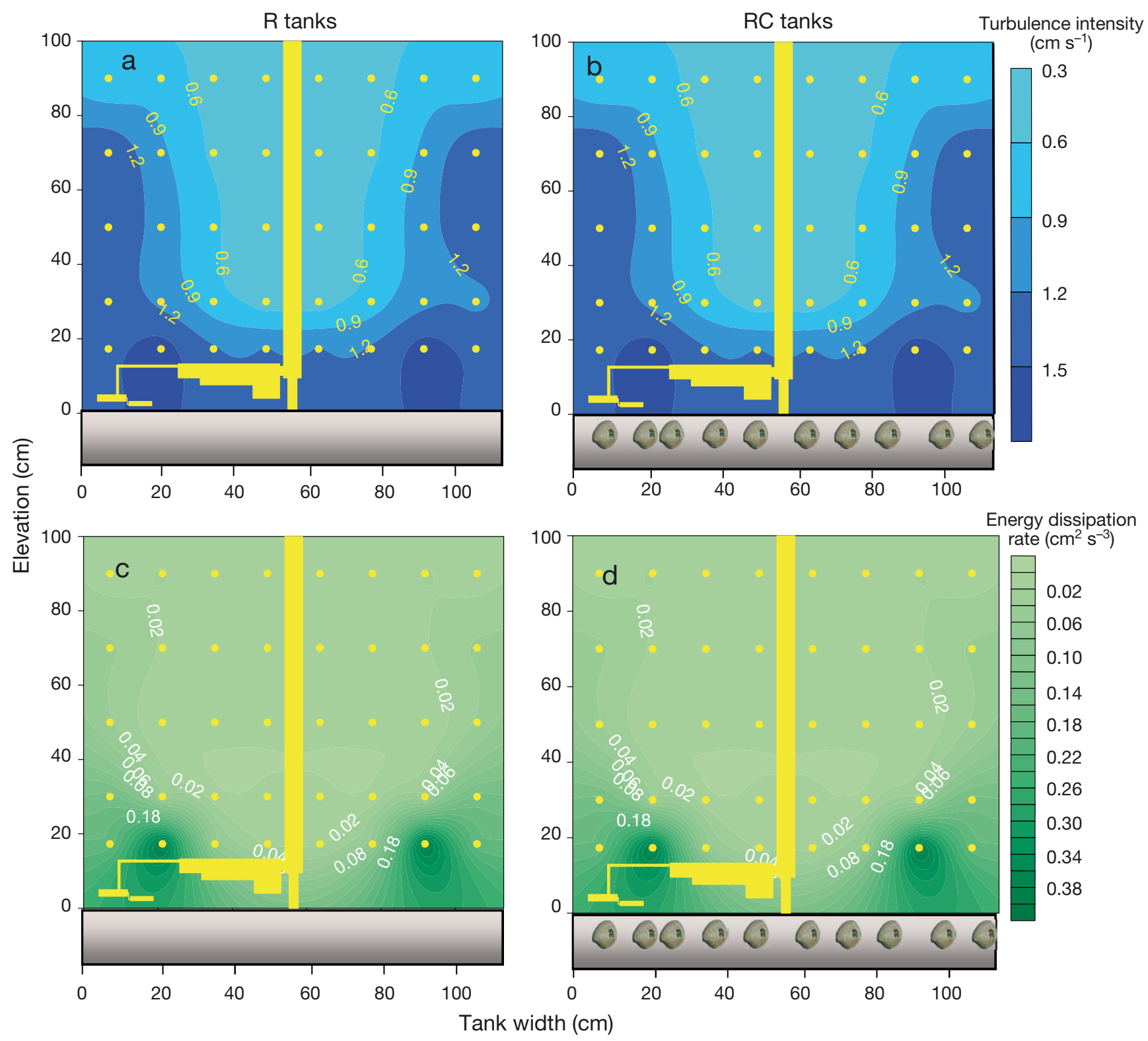

Fig. 1. Turbulence intensity in (a) $3 \mathrm{R}$ tanks and (b) $3 \mathrm{RC}$ tanks during a mixing 'on' phase. Paddles in the tanks indicated in yellow. Energy dissipation rate in the (c) R tanks and (d) RC tanks. The RC tanks contained fifty $40 \mathrm{~mm}$ long hard clams Mercenaria mercenaria (symbols along x-axis). : measurement locations. Tidal cycles ( $4 \mathrm{~h}$ mixing 'on', $2 \mathrm{~h}$ mixing 'off') were generated in all tanks 
We determined shear stress at the bottom directly using hot film anemometry (Gust 1988). Shear (or 'friction') velocity $u_{*}\left(\mathrm{~cm} \mathrm{~s}^{-1}\right)$ was defined as follows:

$$
u_{*}=\sqrt{\frac{\tau_{b}}{\rho}}
$$

where $\tau_{b}$ is bottom shear stress in dynes $\mathrm{cm}^{-2}$, and $\rho$ is the density of water in $\mathrm{g} \mathrm{cm}^{-3}$. The shear velocity was measured at 5 locations across the tank radius. Bottom shear stress (Pa) was calculated as $\tau_{b}=\frac{u_{*}^{2} \rho}{10}$. At the chosen mixing setting, the maximum instantaneous bottom shear stress reached 0.35 to $0.4 \mathrm{~Pa}$ in the tanks (Fig. 2) and produced sediment resuspension, as mediated by bivalves during the mixing-on phases. The spikes in shear stress in Fig. 2 correspond to passage of the paddle directly over the hot film sensor. While the regularity of these spikes is probably not representative of typical turbulent boundary layer flows, similar short-lived bursts of turbulent shear stress have been shown to be present and responsible for sediment resuspension in laboratory flume experiments without paddles (Diplas et al. 2008).

We scaled the biomass of hard clams to high natural densities to filter the entire water column once every $\sim 1.5 \mathrm{~d}$ using literature filtration rates of $32 \mathrm{~mm}$ long clams (Bricelj \& Malouf 1984). Thus, we distributed a total of 50 individually numbered, preweighed, $\sim 40.5 \pm 2 \mathrm{~mm}$ long hard clams in each of 3 tanks, keeping the size distribution between tanks the same. Clam weight gain was determined after the experiment from 91 clams with still identifiable numbers.

\section{Experimental setup}

The mesocosms were prepared with defaunated sediment from Baltimore Harbor (39 $11^{\prime} 29^{\prime \prime} \mathrm{N}, 76^{\circ}$ $31^{\prime} 10.5^{\prime \prime} \mathrm{W}$ ) that was equilibrated to realistic biogeochemical porewater gradients over a $2 \mathrm{wk}$ period in

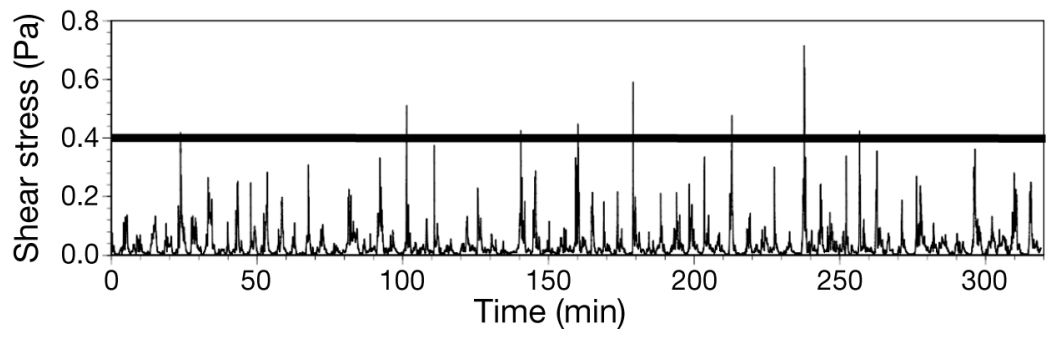

Fig. 2. Bottom shear stress used in all tanks measured with hot-film anemometry after Gust (1988) the dark as described by Porter et al. (2006, their Treatment HD-m), while the initial fill water was unfiltered. Daily water exchange during mixing-off times (10\% exchanged) was with $19 \mathrm{~g} \mathrm{~kg}^{-1}$ filtered water. The collected sediment had a grain size composition of $0 \%$ gravel, $3.27 \%$ sand, $38.7 \%$ silt, and $58.03 \%$ clay by dry weight (Baker et al. 1997). The nitrogen content was $0.37 \%$, and the carbon content was $3.93 \%$ (unpubl. data). Sediment was transported to Chesapeake Biological Laboratory (CBL) and defaunated as described previously (Porter et al. 2006; their Table 2, Treatment HD-m). After defaunation and chemical stabilization, fifty $40 \pm 2 \mathrm{~mm}$ long hard clams were added to each of 3 tanks. Any clams that did not bury were replaced on the second day. The mesocosm experiment began $3 \mathrm{~d}$ later.

We measured light levels of $\sim 227 \mu \mathrm{mol}$ photons $\mathrm{m}^{-2}$ $\mathrm{s}^{-1}$ just below the water surface of the R tanks and RC tanks using an LI-192 Underwater Quantum sensor (LI-COR Biosciences) attached to a model LI-250 readout, which is sufficient to prevent light limitation (Porter et al. 2004a). Therefore, any light limitation within the tanks was due to the impact of resuspension or the presence of the hard clams.

Three days after the hard clams were added, all of the tanks were simultaneously slowly filled with unfiltered $15 \mathrm{~g} \mathrm{~kg}^{-1}$ salinity water from the Patuxent estuary, a tributary of Chesapeake Bay, containing the resident plankton community. Only megazooplankton $>3 \mathrm{~cm}$ were excluded. All tanks were filled with a combination of Patuxent River water and filtered $0.5 \mu \mathrm{m}$ (absolute) $35 \mathrm{~g} \mathrm{~kg}^{-1}$ seawater to achieve the target salinity of $19 \mathrm{~g} \mathrm{~kg}^{-1}$, since a salinity of $18 \mathrm{~g}$ $\mathrm{kg}^{-1}$ is the minimum recommended to avoid growth limitation for Mercenaria mercenaria (R. Grizzle pers. comm.). Mixing began with the programmed tidal cycles, and all tanks were synchronized. On Day 26, the experiment was terminated in the $\mathrm{R}$ tanks because the mixing system failed. The experiment was continued for an additional $5 \mathrm{~d}$ in the RC tanks to follow the trend of total suspended solids (TSS) concentrations that had been in a constant decline.

The water in each tank was removed daily at the end of the mid-day mixing 'off' phase to mimic tidal exchange and replaced with $0.5 \mu \mathrm{m}$ absolute filtered Patuxent estuary water supplemented with instant ocean to achieve a final salinity of $19 \mathrm{~g} \mathrm{~kg}^{-1}$. This water was prepared in an indoor facility $1 \mathrm{~d}$ before each water exchange to ensure all salts were dissolved. We cleaned tank walls of wall periphyton every $2 \mathrm{~d}$ 
to minimize wall growth (Chen et al. 1997) and left the wall material in the tank. On Day 1 of the experiment, we added a nutrient spike with ammonium (25 ml of a solution of $53.5 \mathrm{~g} \mathrm{l}^{-1} \mathrm{NH}_{4} \mathrm{Cl}$ ) and soluble reactive phosphorus ( $25 \mathrm{ml}$ of a solution of $8.51 \mathrm{~g} \mathrm{l}^{-1}$ $\mathrm{KH}_{2} \mathrm{PO}_{4}$ ), in Redfield proportions, to each $1000 \mathrm{l}$ tank to stimulate a phytoplankton bloom as done previously (Porter et al. 2004b, 2010). Immediately after addition, the ammonium concentrations were 27 $\mu \mathrm{mol} \mathrm{l}^{-1}$, and the phosphate concentrations were 1.3 $\mu \mathrm{mol} 1^{-1}$. Silicate was abundant with 30 to $35 \mu \mathrm{mol} \mathrm{l}^{-1}$ at the start of the experiment, and no silicate additions were made. The ecosystem experiment was performed from 25 June 2002 to 25 July 2002 at the Chesapeake Biological Laboratory, University of Maryland Center for Environmental Science in Solomons, MD.

\section{Sampling regime and variables sampled}

The biological and geochemical variables measured included water column chlorophyll a (chl a), phaeophytin, TSS, phytoplankton pigments, water column nutrients, i.e. ammonium, nitrate plus nitrite, dissolved inorganic nitrogen (DIN), phosphate, total nitrogen (TN), and total phosphorus (TP), hard clam live weight change, light profiles, and sediment chl a (see Appendix 1 for details of analytical methods). In addition, we measured particle size spectra during settling during a mixing 'off' phase in all tanks.

We measured turbidity continuously at $1 \mathrm{~s}$ intervals in each tank with optical backscatter (OBS-3, D\&A Instruments) turbidity sensors located at mid-depth. The sensors were calibrated against mid-depth TSS samples. In post-processing, OBS data were averaged over $66 \mathrm{~s}$ intervals. Temperature was measured using Campbell T107 temperature probes connected to a Campbell CR10x data logger (Campbell Scientific) every $10 \mathrm{~min}$ as well as daily using a YSI 6600 instrument during mixing 'on' phases in the afternoon. The 6 tanks tracked each other closely, and the Campbell temperature data were analyzed in detail to determine the temperature variability in the systems.

Dissolved oxygen concentrations were measured during mixing 'on' phases in the afternoon at middepth using a YSI 6600 Sonde. Light penetration was measured every $2 \mathrm{~d}$ during the mixing 'on' and 'off' phases using a PVC cap painted black and white, similar to a Secchi disk, mounted onto a PVC rod and lowered into the water column until it disappeared from view.
We measured light levels twice a week during mixing 'on' phases using a LI-192 Underwater Quantum sensor (LI-COR Biosciences) light meter to measure the total downwelling photosynthetically available radiation (PAR, in the 400 to $700 \mathrm{~nm}$ waveband) at 0 , $10,25,50$, and $65 \mathrm{~cm}$ depth. Light attenuation coefficients and irradiance levels at the sediment surface were determined. In addition, we calculated mean geometric irradiance in the water column as $\exp \{0.5$. $\left.\left[\ln \left(E_{0}\right)+\ln \left(E_{\text {Sed }}\right)\right]\right\}$, where $E_{0}$ and $E_{\text {Sed }}$ are irradiances at the surface of the water column and the sedimentwater interface, respectively. The values obtained for mean geometric irradiance were similar to irradiance values measured at $50 \mathrm{~cm}$ depth.

We took 41 water samples from mid-depth of each tank biweekly during mixing 'on' for particulates and solutes. Water was filtered through $47 \mathrm{~mm}$ Whatman GFF filters (0.7 $\mathrm{mm}$ nominal pore size) and rinsed with an isotonic solution of ammonium formate (Berg \& Newell (1986) to remove salts. TSS, particulate inorganic matter (PIM), and particulate organic matter (POM) levels were determined following techniques by Berg \& Newell (1986). Known volumes of water were filtered through $25 \mathrm{~mm}$ Whatman GFF filters for chl a and phaeophytin concentrations and for particulate nitrogen (PN), particulate phosphorus (PP), and particulate carbon (PC). The filtrate was captured and frozen for analysis for dissolved nutrients including ammonium $\left(\mathrm{NH}_{4}^{+}\right)$, nitrate + nitrite $\left(\mathrm{NO}_{3}{ }^{-}+\mathrm{NO}_{2}^{-}\right)$, dissolved phosphate $\left(\mathrm{PO}_{4}{ }^{3-}\right)$, dissolved silicate $(\mathrm{Si})$, total dissolved nitrogen (TDN), and total dissolved phosphorus (TDP). Exchange water (outflow and fill water) was also sampled for dissolved nutrients to track nutrient inputs or outputs from the $10 \%$ daily water exchange.

On Days 7, 17, and 24, $25 \mathrm{~mm}$ GFF filtered water was used to measure the phytoplankton pigment composition. Folded filters were stored in aluminum foil at $-70^{\circ} \mathrm{C}$ until analysis using high performance liquid chromatography (HPLC; Van Heukelem \& Thomas 2001). Pigments characteristic for phytoplankton in the Chesapeake Bay area, our source water, were used for identification: alloxanthin (Cryptophyceae), fucoxanthin (Chrysophyceae and Bacillariophyceae), lutein (Chlorophyceae and Prasinophyceae), peridinin (Dinophyceae), and zeaxanthin (Cyanobacteria) following Jeffrey \& Vesk (1997), Marshall (1994), and Marshall et al. (2005). We also found the pigment 19'-butanoyloxyfucoxanthin (but-fuco), which is a marker pigment for brown tide organisms Aureococcus anophagefferens (Trice et al. 2004) when 19'-hexanoyloxyfucoxanthin is absent (e.g. compare pigments of Prymnesiophyceae 
and Chrysophyceae in Table 2.3, p. 74-75, in Jeffrey \& Vesk 1997) and when gyroxanthin diester is absent (see Table 50, p. 88-89, in Van Heukelem \& Thomas 2005). Gyroxanthin diester was absent throughout the experiment (C. Thomas pers. comm.). 19'-Hexanoyloxyfucoxanthin was absent except for Day 7 , when it was present only in all RC tanks. Thus, we used but-fuco to indicate the presence of the chrysophyte Aureococcus anophagefferens (Trice et al. 2004). Moreover, Aureococcus anophagefferens has been previously found in Chesapeake Bay water (Marshall et al. 2005), and we observed this species in mesocosm experiments with tidal resuspension (Porter et al. 2010). We normalized the pigment to chl $a$ ratio to account for variance between the $\mathrm{R}$ and $\mathrm{RC}$ tanks. We filtered duplicate subsamples at random for quality control during each sampling. We also collected more frequent samples of TSS during 3 mixing 'off' periods to examine changes in the particulate properties over time during settling.

We measured sediment chl a, phaeophytin, PC, and PN concentrations in the surface sediment as well as the sediment water content at the midpoint of the experiment (on Day 15) and at the end of the experiment. Due to mechanical failure of the mixing system in the R tanks, sediment chl a was sampled on Day 26 in the R tanks, while it was sampled on Day 31 in the RC tanks. At the start of the ecosystem experiment (Day 0), these variables were measured in the benthic chambers set up in parallel to the mesocosm experiment in order to represent the sediment conditions at the start of the experiment. We used $2.5 \mathrm{~cm}$ diameter cutoff syringes with a 1-way valve (BE130-23BB, Instrumentation Industries), affixed to a pole as necessary, as coring devices to sample the tanks for sediment $\mathrm{chl} a$, phaeophytin, $\mathrm{PC}, \mathrm{PN}$, and sediment water content from 3 tank quadrants per tank during the mixing 'on' phase while mixing was briefly turned off. Sediment chl $a$ in the R tanks at the end of the experiment was sampled after mixing was off, and the sediment chl a concentrations were corrected for the settled chl a from the water column using previously obtained measurements. We sampled both the $0-0.5$ and $0.5-1 \mathrm{~cm}$ sediment sections but combined them for data analysis. Sediment chl $a$ and phaeophytin samples were frozen at $-70^{\circ} \mathrm{C}$ pending analysis with HPLC (Van Heukelem \& Thomas 2001). For all variables, the same analytical techniques as described by Porter et al. (2010) were followed (see Appendix 1).

To determine the abundance of any macroinfauna that may have settled or grown up over the $4 \mathrm{wk}$ period of the experiment, we took $13.3 \mathrm{~cm}$ diameter sediment cores from the tanks at the end of the experiment. We washed the contents through a $0.5 \mathrm{~mm}$ diameter mesh, and no macrofauna was found.

Bivalves are known to repackage organic matter into biodeposits, and we expected the size structure and settling of the particles to be different in the $\mathrm{R}$ compared to RC tanks. We used a LISST-100C (laser in situ scattering and transmissometry) instrument to measure particle sizes during settling during 1 mixing 'off' phase in each tank. The LISST was deployed at mid depth during a mixing 'on' phase and recorded particle size distributions at $1 \mathrm{~s}$ intervals throughout the subsequent mixing 'off' phase to examine changes in particle sizes during settling of previously resuspended material. Settling experiments were performed in each of the 6 tanks sequentially on Days 8, 10, 13, and 14. Simultaneous TSS measurements at mid-depth were done using OBS3 instruments, each calibrated using a range of TSS concentrations taken over the course of the experiment. The LISST uses a laser diffraction method for sizing particles, resulting in estimates of particle volume concentration in 32 size classes arranged geometrically between 2.5 and $500 \mu \mathrm{m}$ (Agrawal \& Pottsmith 2004).

\section{Zooplankton}

We sampled mesozooplankton twice a week during mixing 'off' by pumping 401 tank $^{-1}$ at $221 \mathrm{~min}^{-1}$ through a $63 \mu \mathrm{m}$ Nitex screen using a diaphragm pump. The samples were washed into bottles, and mesozooplankton were preserved with buffered formaldehyde. We determined the dominant taxa and age groups on a dissecting microscope using direct counts. To estimate the dry weights (W, $\mu \mathrm{g}$ ind. ${ }^{-1}$ ) of the individuals of different taxa, the number of individuals was multiplied by their taxa's respective weight characteristic (Table 2 in White \& Roman 1992). The dominant taxa were copepod nauplii, Acartia spp. adults, polychaete larvae, and copepodites.

Zooplankton weight was converted to carbon $(\mu \mathrm{g}$ $\mathrm{l}^{-1}$ ) for each taxon, and the taxa were combined for an estimate of combined mesozooplankton biomass to compare to phytoplankton abundance (in a common carbon unit) following White \& Roman (1992, their Table 1: 'Carbon $\left[\mu \mathrm{g} \mathrm{C}\right.$ ind. $\left.{ }^{-1}\right]=0.32 \mathrm{~W}^{\prime}$ ). This was done to examine whether zooplankton affected phytoplankton biomass in addition to the effect of hard clams. A POC to chl a ratio of 51.68 (Porter et al. 2010) was used to convert phytoplankton biomass to 
phytoplankton carbon. Linear regression analyses were performed using SAS (SAS Institute). In addition, we estimated the nitrogen content of the zooplankton community for an overall nitrogen budget.

\section{Nitrogen budget}

We also estimated nitrogen budgets in the R and RC tanks, based on data from Day 7 to the experiment end, which excluded the nutrient spike. Nutrient inputs and outputs with the exchange water were taken into consideration. Inputs for the RC tanks were $6 \mu \mathrm{g}$ $\mathrm{l}^{-1} \mathrm{chl} \mathrm{a}, 20 \mathrm{~g}$ dry tissue weight clams, $10 \mu \mathrm{mol} \mathrm{l}^{-1}$ DIN, and $26 \mu \mathrm{mol} \mathrm{l}^{-1}$ DON. Inputs for the $\mathrm{R}$ tanks were 25 $\mu \mathrm{g} \mathrm{l}^{-1} \mathrm{chl} \mathrm{a}, 2 \mu \mathrm{mol} \mathrm{l} \mathrm{l}^{-1} \mathrm{DIN}$, and $21 \mu \mathrm{mol} \mathrm{l}^{-1}$ DON. Zooplankton inputs for the RC tanks were 3 Acartia ind. $\mathrm{l}^{-1}, 4$ copepodites $\mathrm{l}^{-1}, 22$ polychaete larvae $\mathrm{l}^{-1}$, and 30 copepod nauplii $\mathrm{l}^{-1}$. Zooplankton inputs for the $\mathrm{R}$ tanks were 3 Acartia ind. $\mathrm{l}^{-1}, 1$ copepodite $\mathrm{l}^{-1}, 22$ polychaete larvae $\mathrm{l}^{-1}$, and 29 copepod nauplii $\mathrm{l}^{-1}$. Microphytobenthos inputs were 14 and $27 \mathrm{mg} \mathrm{chl} a \mathrm{~m}^{2}$ in the RC and R tanks, respectively. Water-column chl $a$ was converted to nitrogen equivalents (phytoplankton biomass nitrogen, $\mu \mathrm{mol} \mathrm{N}_{\text {tank }}{ }^{-1}$ ) using the ratio of POC to chl $a$ of 51.68 and a C:N ratio of 5.138 (Porter et al. 2010). Sediment chl $a$, indicative of microphytobenthos abundance, was converted to nitrogen equivalents $\left(\mu \mathrm{mol} \mathrm{N} \operatorname{tank}^{-1}\right)$ in the same way. The $\mathrm{N}$ content of the zooplankton community was calculated from dry weights of the individuals of the different taxa, following White \& Roman (1992) and measured abundances. The nitrogen content was determined as $7.5 \%$ of the mesozooplankton dry weight (5 to $10 \%$ of mesozooplankton dry weight is nitrogen; Parsons et al. 1984). Water-column concentrations of TDN were scaled up to the whole tank.

\section{Statistical analyses}

Statistical approaches are detailed by Porter et al. (2010). Most parameters were each averaged from Day 6 to Day 24 of the experiment for each tank (ca. 6 measurements over a 3 wk period). As in Porter et al. (2010), data from the first $5 \mathrm{~d}$ of the experiment were not included to avoid the immediate effects of the initial nutrient spike. Mesozooplankton abundance for each tank was averaged from Day 6 to 25 . Only data from the mixing 'on' phases were included in statistical comparisons. Statistical $t$-tests were used for most water-column parameters. We used split plot analyses in time for sediment chl a over the duration of the experiment. We used linear regression analyses of mesozooplankton biomass and phytoplankton biomass to determine the relationship between these communities. Statistical analyses were performed using SAS (SAS Institute), and the $t$-tests were conducted using the Microsoft Excel Analysis tool pack. Significances of all analyses were defined at the $\mathrm{p} \leq 0.05$ level.

\section{RESULTS}

\section{Water-column processes}

Water temperatures (means $\pm \mathrm{SD}$ ) ranged from 22.8 to $29.6^{\circ} \mathrm{C}$ in the $\mathrm{RC}$ tanks $\left(26.37 \pm 0.02^{\circ} \mathrm{C}\right)$ and from 22.7 to $29.2^{\circ} \mathrm{C}\left(25.96 \pm 0.01^{\circ} \mathrm{C}\right)$ in the R tanks. Dissolved oxygen concentrations were significantly lower in the RC tanks compared to the R tanks (Fig. 3), with conditions being hypoxic in the RC tanks during the first week of the experiment.

TSS concentrations were significantly higher in the tanks with hard clams (RC: $180 \mathrm{mg} \mathrm{l}^{-1}$ on Day 1; R: $\sim 30 \mathrm{mg} \mathrm{l}^{-1}$; Fig. 4). Throughout the experiment, TSS concentrations were $\sim 50 \mathrm{mg} \mathrm{l}^{-1}$ in the $\mathrm{R}$ tanks but in the RC tanks continuously decreased from $\sim 200 \mathrm{mg}$ $\mathrm{l}^{-1}$ on Day 2 to $\sim 60 \mathrm{mg} \mathrm{l}^{-1}$ on Day 20 and then remained at $\sim 60 \mathrm{mg} \mathrm{l}^{-1}$ until the end of the experiment on Day 31. During mixing 'off' phases, TSS concentrations were $\sim 5$ to $15 \mathrm{mg} \mathrm{l}^{-1}$ in the $\mathrm{RC}$ and the $\mathrm{R}$ tanks. PC, PN, and PP concentrations were linearly related to TSS concentrations, and PC and PP concentrations were significantly enhanced in the RC tanks. TSS concentrations were significantly higher in the RC tanks than in the R tanks.

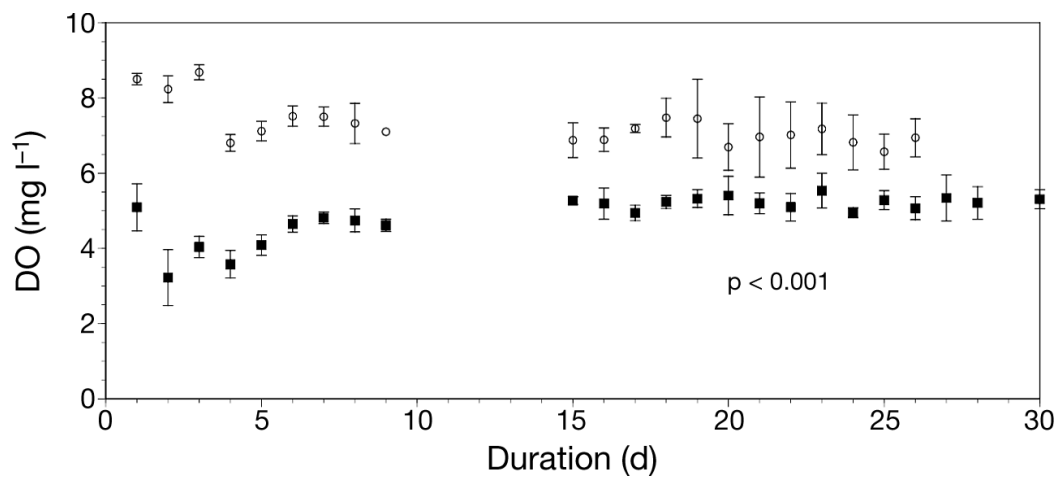

Fig. 3. Dissolved oxygen (DO) concentrations over the experiment. Means $\pm S D$, $\mathrm{n}=3$ tanks for each system. Values $<5 \mathrm{mg} \mathrm{l}^{-1}$ indicate hypoxia. Statistical results indicated with $\mathrm{p}$-value, statistical significance $\mathrm{p}<0.05$. $\mathbf{\text { : }} \mathrm{RC}$ tanks, $\mathrm{o}$ : R tanks 


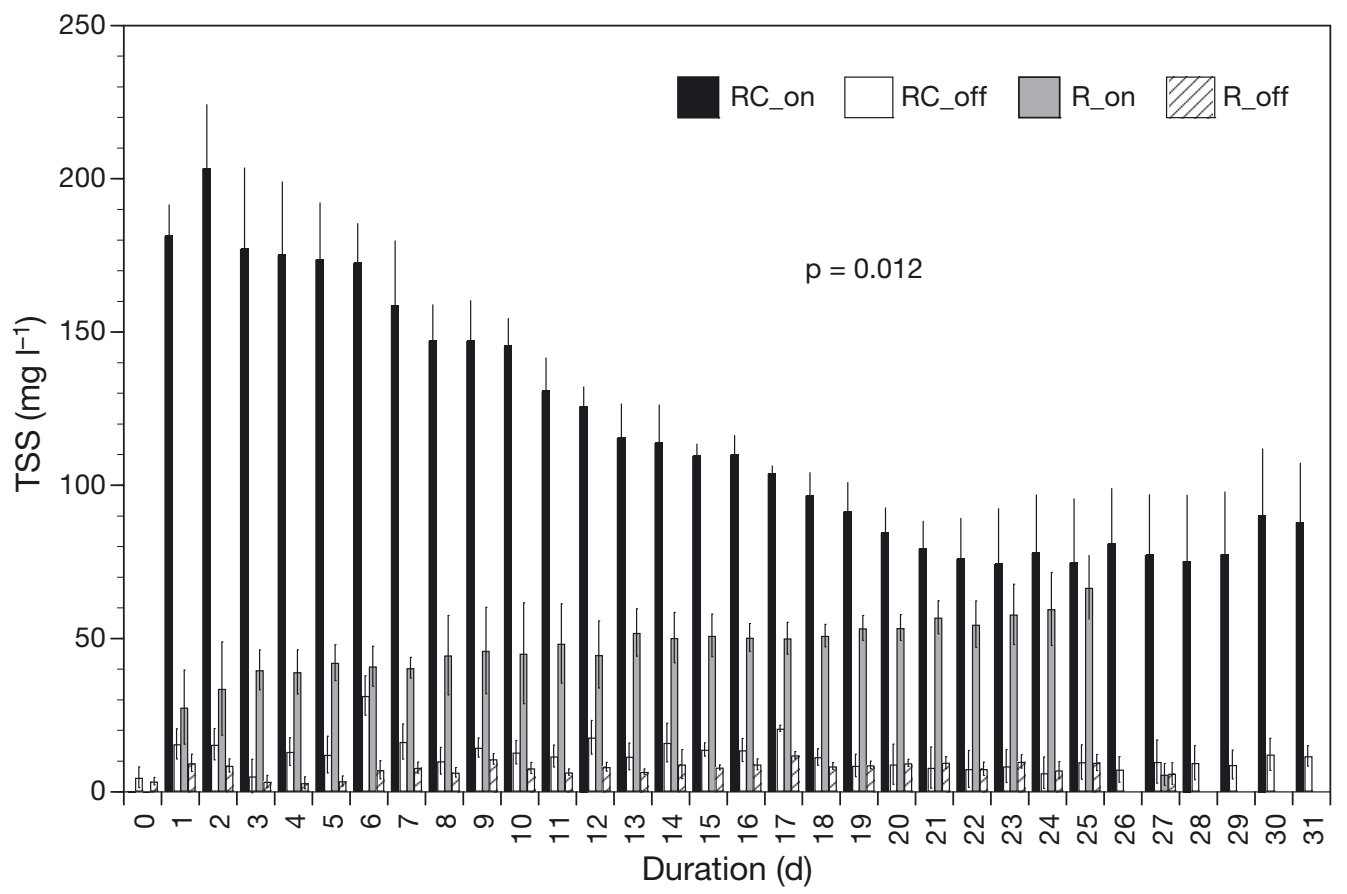

Fig. 4. (a) Total suspended seston (TSS) concentrations (mean $\pm \mathrm{SD}, \mathrm{n}=3$ tanks for each system and mixing phase) over time in the $\mathrm{RC}$ and the R tanks during the mixing 'on' phases and the mixing 'off' phases as measured using OBS3 sensors, calibrated with TSS samples. Samples on Day 0 were taken before mixing was started. Difference between R_on and RC_on statistically significant $(\mathrm{p}<0.05)$
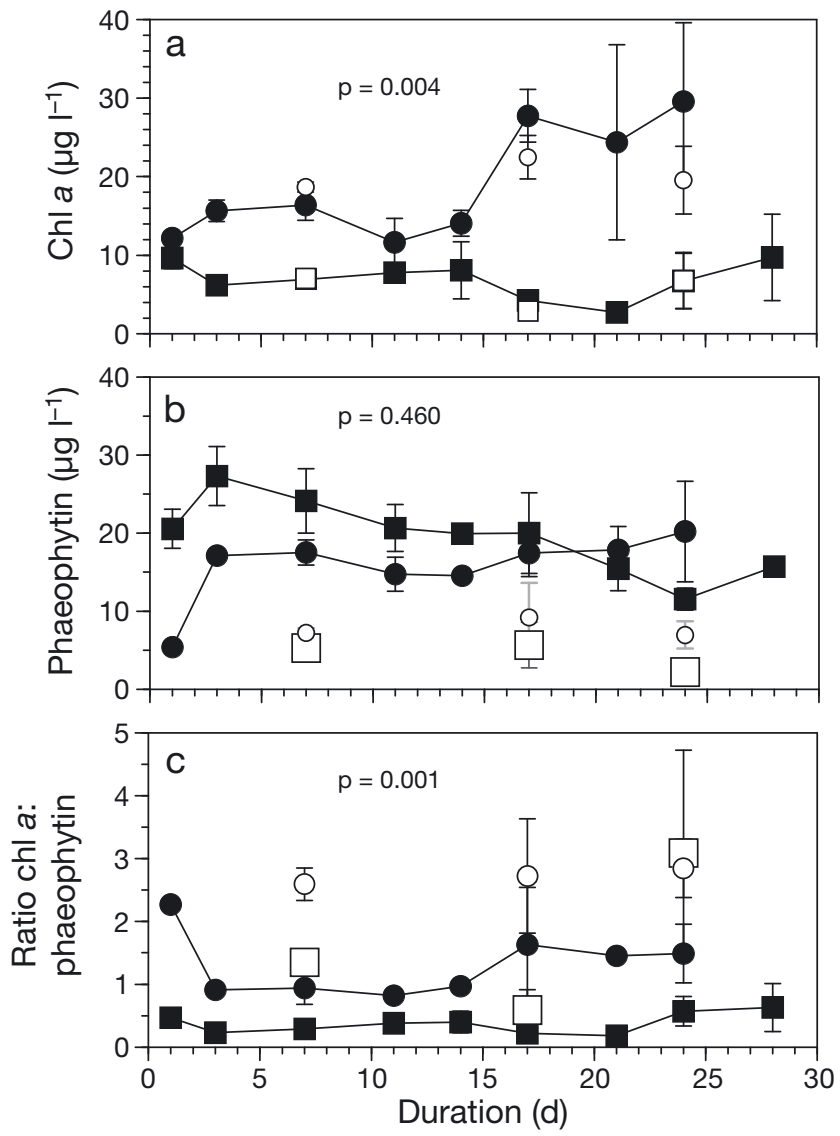

Water-column chl a (11 to $\left.30 \mu \mathrm{g} \mathrm{l}^{-1}\right)$ levels were significantly higher in the R tanks than in the RC tanks ( 2 to $10 \mu \mathrm{g} \mathrm{l}^{-1}$ ), and while a phytoplankton bloom developed in the R tanks, this did not occur in the RC tanks (Fig. 5a). While a portion of the chl a settled and was resuspended with the mixing 'on' and 'off' cycles in the R tanks, it was concluded that chl a did not substantially resuspend and settle in the RC tanks (Fig. 5a) as chl a concentrations were the same during the mixing 'on' and 'off' phases. Clams likely fed on the microphytobenthos as it was resuspended. Phaeophytin concentrations differed significantly between the mixing 'on' and the mixing 'off' phases as degraded material was resuspended and deposited (Fig. 5b). The ratio of chl a to phaeophytin was 2- to 4-fold higher in the $\mathrm{R}$ compared to the $\mathrm{RC}$ tanks (Fig. 5c). Assuming that the ratios of chl a:phaeophytin would have been the same in the R and RC tanks in the absence of clam grazing, we can use this assumption to calculate the expected concentration

Fig. 5. (a) Chlorophyll a (chl a), (b) phaeophytin, and (c) ratio of chl $a$ and phaeophytin concentrations (mean $\pm \mathrm{SD}, \mathrm{n}=3$ tanks for each system and mixing phase) over time in the $\mathrm{R}$ versus the $\mathrm{RC}$ tanks during the mixing 'on' and 'off' phases. Difference between values statistically significant ( $\mathrm{p}<0.05)$. @: R_on, $\mathbf{\square}$ : RC_on, O: R_off, $\square$ : RC_off 
in the $\mathrm{RC}$ tanks: $\mathrm{RC}_{\text {Chla }}=\mathrm{RC}_{\text {Phae }} \cdot\left(\mathrm{R}_{\text {Chla }} / \mathrm{R}_{\text {Phae }}\right)$, where $\mathrm{RC}_{\text {Chla }}$ removed is $\mathrm{RC}_{\text {Chla }}$ expected $-\mathrm{RC}_{\text {Chla }}$ actual. Thus, we estimate the amount of chl a removed by the clams as $15.25 \mathrm{mg}$ chl a per tank daily from Day 7 to Day 24 of the experiment, with peak removal rates of $27 \mathrm{\mu g} \mathrm{l}^{-1} \mathrm{~d}^{-1}$ or $27 \mathrm{mg}$ per tank on Day 17 of the experiment. This is $7 \mathrm{mg}$ chl a or $373 \mathrm{mg}$ carbon removed per clam over the experiment. About one third of the phytoplankton can be resuspended microphytobenthos (Fig. 5a), so $250 \mathrm{mg}$ phytoplank-
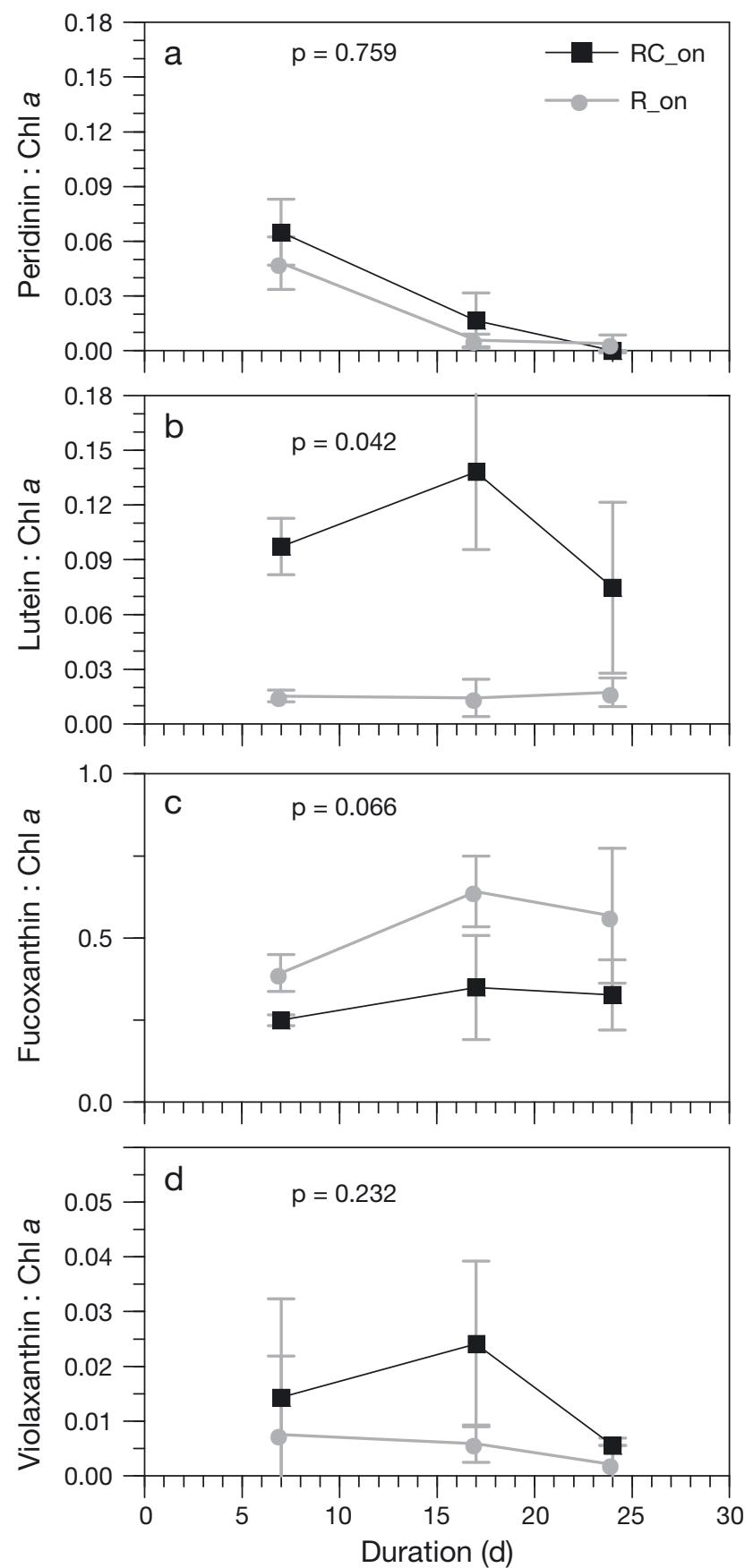

ton carbon were removed over the experiment. Assuming a $10 \%$ trophic transfer to biomass (Reece et al. 2011), this suggests that each clam should have gained $25 \mathrm{mg}$ carbon over the experiment from feeding on phytoplankton alone.

Phytoplankton community structure was affected by resuspension and hard clams (Fig. 6). Lutein, indicative of Chlorophyceae and Prasinophyceae, was significantly higher in the RC tanks than in the R tanks (Fig. 6b). But-fuco, which is indicative of Aure-
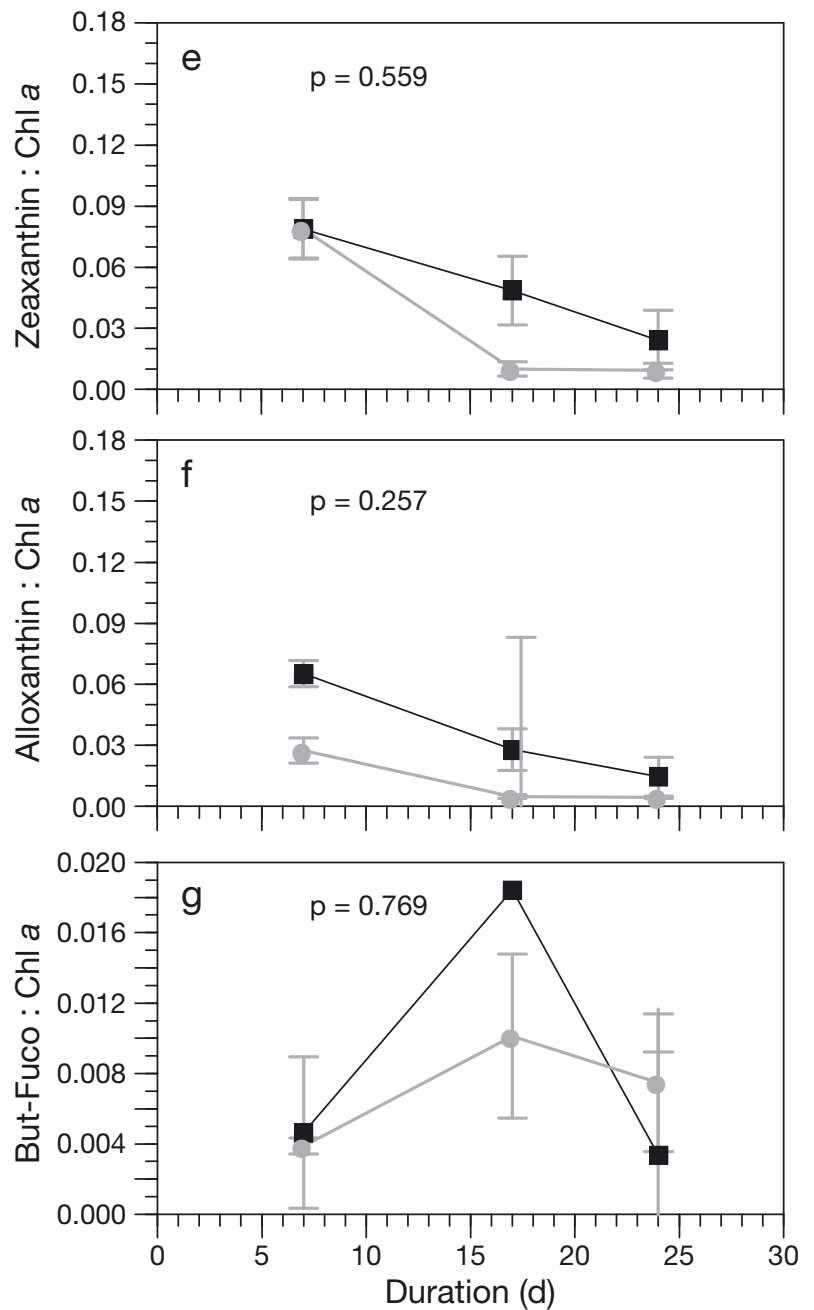

Fig. 6. (a-g) Phytoplankton accessory pigment to chlorophyll a ratios. Chl a: chlorophyll $a$, 'But-Fuco': 19'-butanoyloxyfucoxanthin, a marker pigment for brown tide algae Aureococcus anophagefferens if gyroxanthin diester and 19'-hexanoyloxyfucoxanthin are absent (see 'Sampling regime and variables sampled'). Means $\pm \mathrm{SD}, \mathrm{n}=3$ tanks for each system. Differences statistically significant if $p<0.05$ 
ococcus anophagefferens, was found in all samples (Fig. 6g) with 19'-hexanoyloxyfucoxanthin and gyroxanthin diester being absent, except for Day 7 where 19 '-hexanoyloxyfucoxanthin was present in the RC tanks indicating Prymnesiophyceae. But-fuco concentrations reached Category I bloom conditions of Aureococcus anophagefferens in 2 of the $3 \mathrm{RC}$ tanks on Day 17 (8049 and 1375 cells ml $^{-1}$, respectively, based on cell count conversions by Trice et al. 2004) but did not reach bloom conditions in the $\mathrm{R}$ tanks. Levels of fucoxanthin, indicative of Chrysophyceae and Bacillariophyceae (Fig. 6c), peridinin indicating Dinophyceae (Fig. 6a), and zeaxanthin indicating Cyanobacteria (Fig. 6e) were similar in the RC and R tanks.

Nutrient concentrations were consistent with the differences noted above for algal biomass (Fig. 7b-e). Nitrate plus nitrite (Fig. 7a), dissolved $\mathrm{PO}_{4}{ }^{3-}$ (Fig. 7C), DON (Fig. 7h), total dissolved nitrogen (Fig. 7e), and phosphorus concentrations (Fig. 7f) were significantly higher in the RC tanks than in the R tanks. As chl $a$ increased in the $\mathrm{R}$ tanks (Fig. 5a), nitrate + nitrite (Fig. 7a), ammonium, and dissolved $\mathrm{PO}_{4}{ }^{3-}$ levels decreased.

Defining nutrient limitation as dissolved silicate $<5$ $\mu \mathrm{mol} \mathrm{l} \mathrm{l}^{-1}$, DIN $<2 \mu \mathrm{mol} \mathrm{l} \mathrm{l}^{-1}$, and $\mathrm{PO}_{4}{ }^{3-}<0.1 \mu \mathrm{mol} \mathrm{l} \mathrm{l}^{-1}$ (Fisher et al. 1992; T. Fisher, Horn Point Laboratory, University of Maryland Center for Environmental Science, pers. comm.), all nutrients became limiting in the R tanks after Day 17 (Fig. 7d,b,c). However, nutrient addition bioassays, such as those used by Fisher et al. (1999), would be needed to confirm which was the limiting nutrient. In contrast, the RC tanks generally did not meet the Fisher et al. (1992) criteria for nutrient limitation (Fig. 7b-d). Dissolved organic phosphorus concentrations were similar between the RC and the R tanks (Fig. 7g).

At the beginning of the experiment, total nitrogen $\left(\mathrm{NH}_{4}{ }^{+}+\mathrm{NO}_{2}{ }^{-}+\mathrm{NO}_{3}{ }^{-}+\right.$ $\mathrm{DON}+\mathrm{PN}$ ) concentrations were about twice as high in the RC tanks as in the $\mathrm{R}$ tanks and decreased over time to become similar to the $\mathrm{R}$ tanks by the last week of the experiment (Fig. 7j). Total phosphorus concentrations $\left(\mathrm{PO}_{4}{ }^{3-}+\mathrm{DOP}+\mathrm{PP}\right)$ were $\sim 4$-fold higher in the RC tanks than the R tanks at the beginning of the experiment (Fig. 7k) and decreased over time to become similar to the $\mathrm{R}$ tanks by the last week of the experiment. The pattern of TP and TN progressions (Fig. $7 \mathrm{j}, \mathrm{k}, \mathrm{l}$ ) were similar to the patterns
Fig. 7. Dissolved and particulate nutrient concentrations (mean $\pm \mathrm{SD}, \mathrm{n}=3$ tanks for each system). (a) Nitrite + nitrate $\left(\mathrm{NO}_{2}{ }^{-}+\mathrm{NO}_{3}{ }^{-}\right.$), (b) dissolved inorganic nitrogen (DIN), (c) phosphate $\left(\mathrm{PO}_{4}{ }^{3-}\right)$, (d) dissolved silicate, (e) total dissolved nitrogen (TDN), (f) total dissolved phosphorus (TDP), (g) dissolved organic phosphorus (DOP), (h) dissolved organic nitrogen (DON), (i) ammonium $\left(\mathrm{NH}_{4}{ }^{+}\right)$, (j) total nitrogen (TN), (k) total phosphorus (TP), and (l) ratio of TN to TP. Vertical line in $\mathrm{b}$ and $\mathrm{c}$ : nutrient spike of nitrogen and phosphorus added to the water column. Horizontal dashed lines in b, c, and d: thresholds for nutrient limitation for the respective nutrients (see 'Water column processes'). Statistical results indicated with $\mathrm{p}$ value, statistical significance $\mathrm{p}<0.05$

of the TSS concentrations over time, which suggests that resuspended sediment may have been a source of additional nutrients. Most of these increases in TP and TN were due to resuspended PP and TN, respectively, which was related linearly to TSS levels (PP $\mathrm{mg} \mathrm{l}^{-1}=0.00292 \cdot \mathrm{TSS} \mathrm{mg} \mathrm{l}^{-1}+0.0083, \mathrm{R}^{2}=0.99 ; \mathrm{PN}$

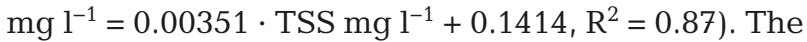
nitrogen budget (Table 1) showed the partitioning of nitrogen into zooplankton, phytoplankton, microphytobenthos, DON, DIN, hard clams, and porewater nitrogen. Seston quality (ratio of particulate organic matter to particulate inorganic matter, means $\pm \mathrm{SD}$ ) was significantly better in the R tanks $(0.232 \pm 0.006)$ than in the RC tanks $(0.170 \pm 0.005, \mathrm{p}<0.001)$.

\section{Particle settling}

Settling during the mixing 'off' phases showed similar patterns of settling and particle distributions in all of the systems (Fig. 8). Although TSS levels were $~ 3-$ fold higher in the RC tanks at the beginning of the settling period, both the rates of settling and the eventual steady state TSS concentrations were approximately the same in all tanks. Almost all of the material that

Table 1. Partitioning of nitrogen $(\mathrm{N})$ within the resuspension $(\mathrm{R})$ and resuspension with 50 clams (RC) tanks (see 'Discussion'). DIN: dissolved inorganic nitrogen (ammonium + nitrate + nitrite), DON: dissolved organic nitrogen. Porewater N estimates for R are taken from Porter et al. (2010)

\begin{tabular}{|c|c|c|c|c|}
\hline \multirow[t]{2}{*}{ Variable } & \multicolumn{2}{|c|}{$\mathrm{R}$ tanks } & \multicolumn{2}{|c|}{$-\mathrm{RC}$ tanks } \\
\hline & $\begin{array}{c}\mathrm{N} \\
\left(\mu \mathrm{mol} \operatorname{tank}^{-1}\right)\end{array}$ & $\begin{array}{c}\text { Distrib. } \\
(\%)\end{array}$ & $\begin{array}{c}\mathrm{N} \\
\left(\mu \mathrm{mol} \operatorname{tank}^{-1}\right)\end{array}$ & $\begin{array}{c}\text { Distrib. } \\
(\%)\end{array}$ \\
\hline Zooplankton & 337 & 0.6 & 392 & 0.7 \\
\hline Phytoplankton & 14813 & 24.9 & 4372 & 7.6 \\
\hline Microphytobenthos & 19318 & 32.5 & 9864 & 17.0 \\
\hline DON & 21507 & 36.2 & 25906 & 44.7 \\
\hline DIN & 2922 & 4.9 & 10453 & 18.1 \\
\hline Mercenaria mercenaria & 0 & 0.0 & 5927 & 10.2 \\
\hline Porewater N & 490 & 0.8 & 989 & 1.7 \\
\hline Total N ( $\mu$ mol N per tank) & 59387 & 100.0 & 57903 & 100.0 \\
\hline
\end{tabular}



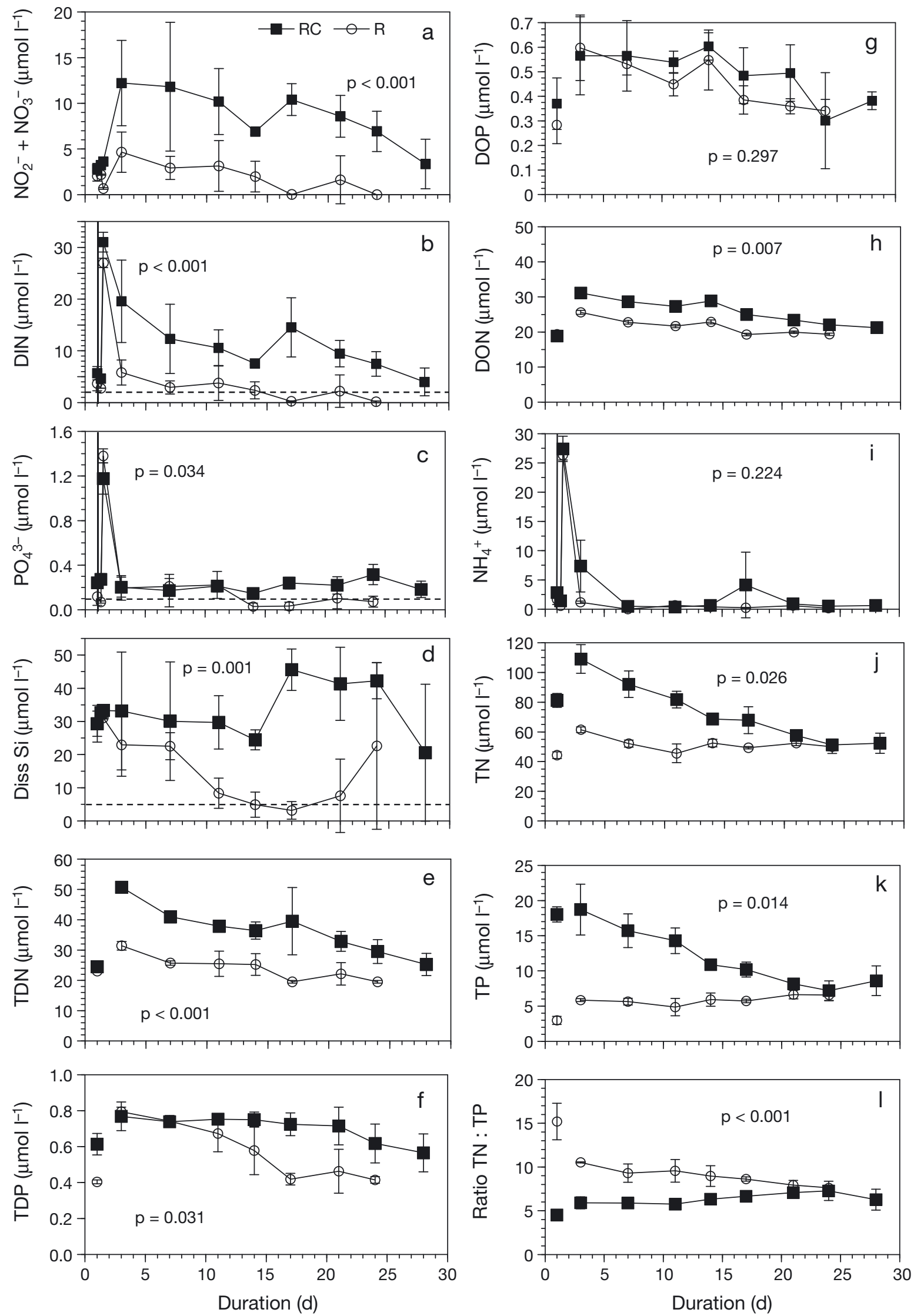
settled did so within the first $30 \mathrm{~min}$. Particles were dominated by particulate inorganic matter. Defining an estimate of the bulk settling velocity as the distance from the surface to the turbidity sensor $(0.5 \mathrm{~m}$ depth) divided by the time to reduce the initial TSS concentration by $50 \%$ of the range to its steady state value, we estimated bulk settling velocities ranging between 0.9 and $1.7 \mathrm{~mm} \mathrm{~s}^{-1}$ with an average of 1.2 $\mathrm{mm} \mathrm{s}^{-1}$. There was no significant difference in settling velocity between the RC and R tanks. Particle size distributions (PSDs) from the LISST100C measurements showed, however, that settling was a dynamic process. During the first short period ( $90 \mathrm{~s})$ after settling began, the initial PSD simply decreased in magnitude without changing shape. Flocculation became apparent immediately afterward, with the sudden appearance of a peak in the largest sizes of the PSD. The average median diameter $\left(D_{50}\right)$ during the $2 \mathrm{~h}$ settling period for all of the experiments was $86 \mu \mathrm{m}$. Floc diameters tended to be larger during the first $15 \mathrm{~min}$ (average of $117 \mu \mathrm{m}$ ). There was no significant difference in particle size between the RC and R tanks.

\section{Light penetration and microphytobenthos levels}

Measured bottom irradiance levels during the resuspension phase were low at $\sim 1$ and $2 \mu \mathrm{mol}$ photons $\mathrm{m}^{-2} \mathrm{~s}^{-1}$ (Fig. 9a). While irradiance at the sediment surface was similar in the RC and R systems (Fig. 9a), geometric mean irradiance in the water column was higher in the R tanks (18.3 $\mu$ mol photons) than in the RC tanks (8.9 $\mu \mathrm{mol}$ photons), which had higher TSS concentrations.

Light penetration, as measured by a home-made Secchi disk, penetrated $\sim 40 \mathrm{~cm}$ into the $\mathrm{R}$ tanks during resuspension (Fig. 9b). During the 'off' phases, light in the R tanks occasionally reached to the bottom (Fig. 9b). In the RC tanks, light reached only $15 \mathrm{~cm}$ into the water column at the start of the experiment and reached $\sim 40 \mathrm{~cm}$ by the end of the experiment during the 'on' phase, similar to the R tanks. At the end of the experiment, light reached the bottom during 'off' phases in the RC tanks, whereas in the R tanks, light reached $\sim 85 \mathrm{~cm}$ into the water column (Fig. 9b), with implications for potential microphytobenthos growth.
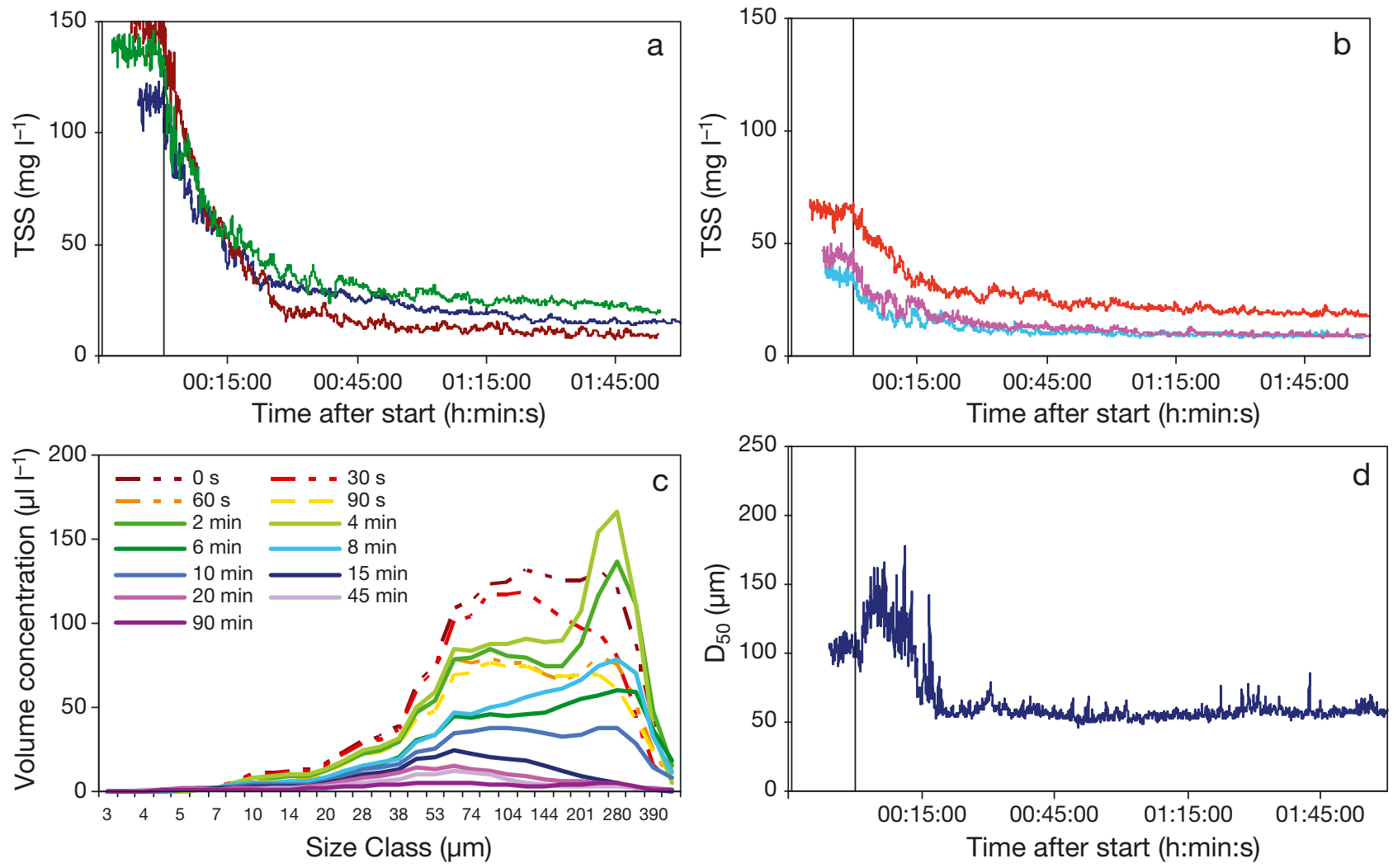

Fig. 8. Total suspended sediment (TSS) concentration time series during settling experiments in (a) 3 RC tanks and (b) 3 R tanks. Experiments were run in different tanks on Days 8, 10,11, and 14. Vertical lines in panels a, b, and d mark the mixing 'off' time and the beginning of settling. (c) Sequence of particle size distributions measured with a LISST-100C in a RC tank during settling, typical of all of the tanks. Flocculation is apparent between $\sim 2$ and 15 min after mixing 'off'. (d) Median particle diameter $\left(D_{50}\right)$ time series from the same RC tank, showing the formation and settling of large flocs during the first 15 min of settling 


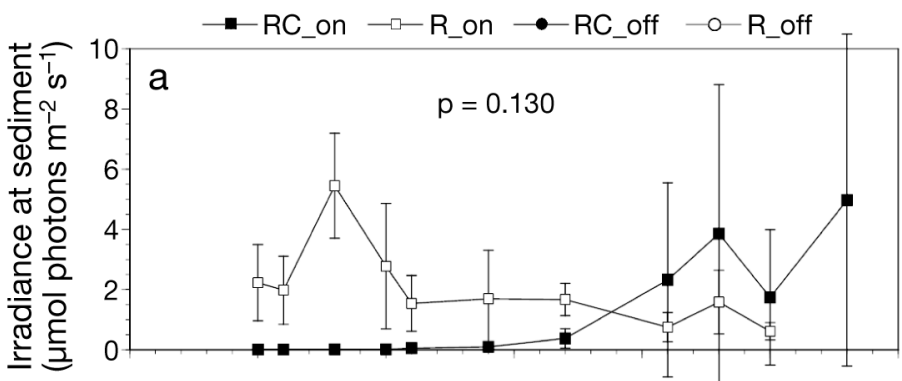

Water surface

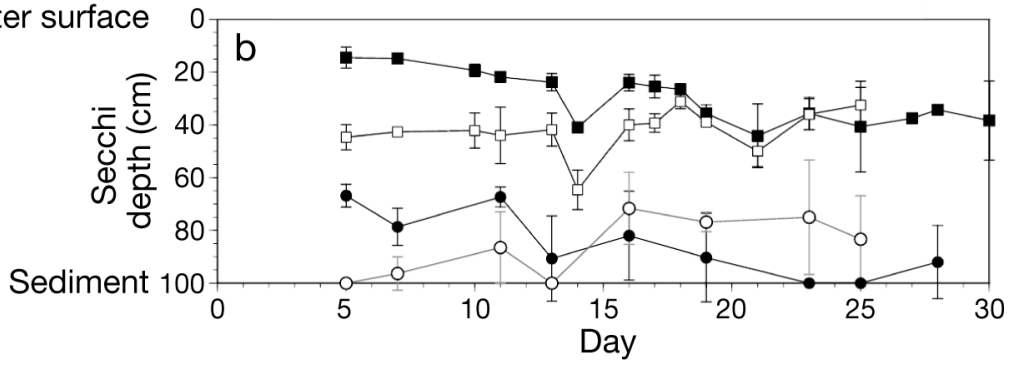

Fig. 9. (a) Irradiance calculated at the sediment surface during the mixing 'on' phases; $\mathrm{n}=3$ for each system, mean \pm SD. (b) Secchi depth measured in the $\mathrm{R}$ and $\mathrm{RC}$ tanks during the mixing 'on' and 'off' phases over the experiment. Irradiance at the sediment was not significantly different, statistical significance $\mathrm{p}<0.05$

Sediment chl a concentrations were low overall but varied significantly between systems and over time. Sediment chl a levels were significantly higher in the R tanks (Fig. 10), which had a higher geometric mean irradiance and lower TSS levels but lacked clams. Sediment chl a levels increased from $\sim 5 \mathrm{mg} \mathrm{m}^{-2}$ initially to $\sim 13$ and $18 \mathrm{mg} \mathrm{m}^{-2}$ midway through the experiment to $\sim 14 \mathrm{mg} \mathrm{m}^{-2}$ and $26 \mathrm{mg} \mathrm{m}^{-2}$ in the RC and $\mathrm{R}$ tanks, respectively. We estimated how much sediment chl a: was eaten by the clams. Assuming

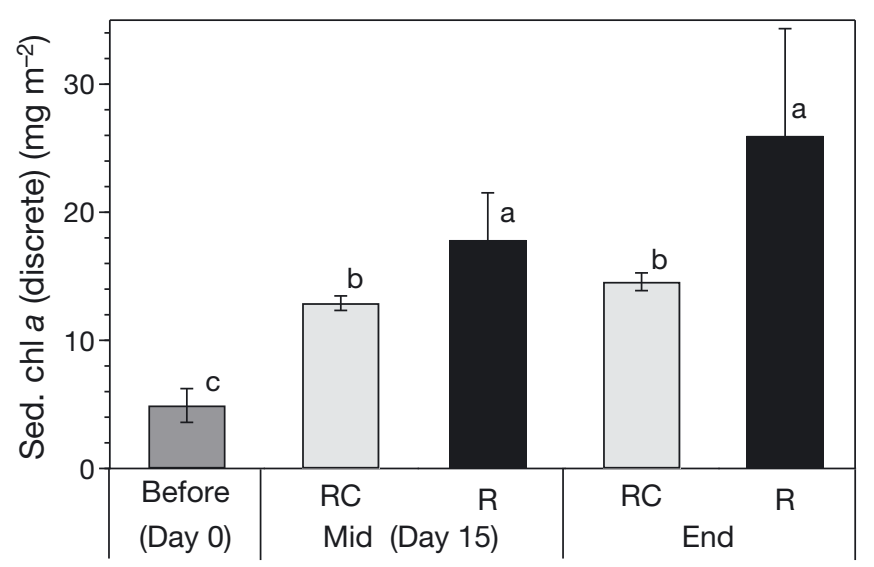

Fig. 10. Sediment (Sed.) chl a levels in the 0 to $1 \mathrm{~cm}$ depth section of sediment at the beginning (Day 0), on Day 15, and at the end of the experiment (Day 26 in the R tanks, Day 31 in the RC tanks), measured using HPLC. Different letters indicate statistically significant differences at $p<0.05$. Means $\pm \mathrm{SD}, \mathrm{n}=3$ for each system that the ratios of chl a/phaeophytin would have been the same in the $\mathrm{R}$ and $\mathrm{RC}$ tanks in the absence of clams, we can use that assumption to calculate the expected concentration in the $\mathrm{RC}$ tanks: $\mathrm{RC}_{\text {SedChla }}=\mathrm{RC}_{\text {SedPhae }} \cdot\left(\mathrm{R}_{\text {Sed- }}\right.$ $\mathrm{Chla}_{2} / \mathrm{R}_{\text {SedPhae), }}$, where $\mathrm{RC}_{\text {SedChla }}$ removed is $\mathrm{RC}_{\text {SedChla }}$ expected $-\mathrm{RC}_{\text {SedChla }}$ actual. Thus, the amount of sediment chl a removed by the clams mid-experiment was $0.068 \mathrm{mg} \mathrm{m}^{-2}$ or $3.5 \mathrm{mg}$ microphytobenthos carbon and by the end was $0.40 \mathrm{mg} \mathrm{m}^{-2}$ or $20.9 \mathrm{mg}$ microphytobenthos carbon. Thus, $250 \mathrm{mg}$ phytoplankton carbon and 8.1 microphytobenthos carbon combined were consumed per clam over the experiment. Other variables (particulate carbon and nitrogen concentrations and water content in the top $0.5 \mathrm{~cm}$ of sediment) were not significantly different between treatments.

\section{Macroinfauna and mesozooplankton}

The sediment had been defaunated at the start of the experiment, and no macrofauna, besides the added Mercenaria mercenaria, developed in the RC or the R tanks over the course of the experiment. $M$. mercenaria live weight increased over the experiment in the $3 \mathrm{RC}$ tanks by $0.135,10.2$, and $5.037 \mathrm{~g} \mathrm{(50}$ clams each) or by $103 \pm 101 \mathrm{mg}$ live weight per clam over the experiment. Converting live weight to carbon based on Frithsen et al. (1986) and length weight relationships, $6.2 \mathrm{mg}$ carbon were gained per clam over the experiment. Assuming a trophic transfer efficiency of $10 \%$ (Reece et al. 2011), $62 \mathrm{mg}$ carbon would be needed per clam over the experiment to achieve this weight. This estimate is within a factor of 4 of the value estimated above based on changes in phytoplankton biomass. Possible reasons for the differences in the 2 estimates is that we are assuming phytoplankton changes between the RC and R tanks are entirely due to clam feeding; however, differences in other factors, including differences in light, phytoplankton species composition, and the composition of the zooplankton between the RC and R tanks, could have all partially influenced the direct validity of the assumption. In addition, we used a POC:chl a ratio of 51.8 (Porter et al. 2010), and there is evidence that the ratios can vary depending on species composition (de Jonge 1980, Harding et al. 
2002). Overall, given the basis of the calculations, the overall agreement between the estimates suggests that the differences between the $\mathrm{RC}$ and $\mathrm{R}$ tanks in phytoplankton abundance were most likely due to clam feeding.

Dominant mesozooplankton taxa found in the water column were adult Acartia sp. copepods, copepodites, copepod nauplii, and polychaete larvae (Fig. 11). Pumps likely destroyed the adult mesozooplankton
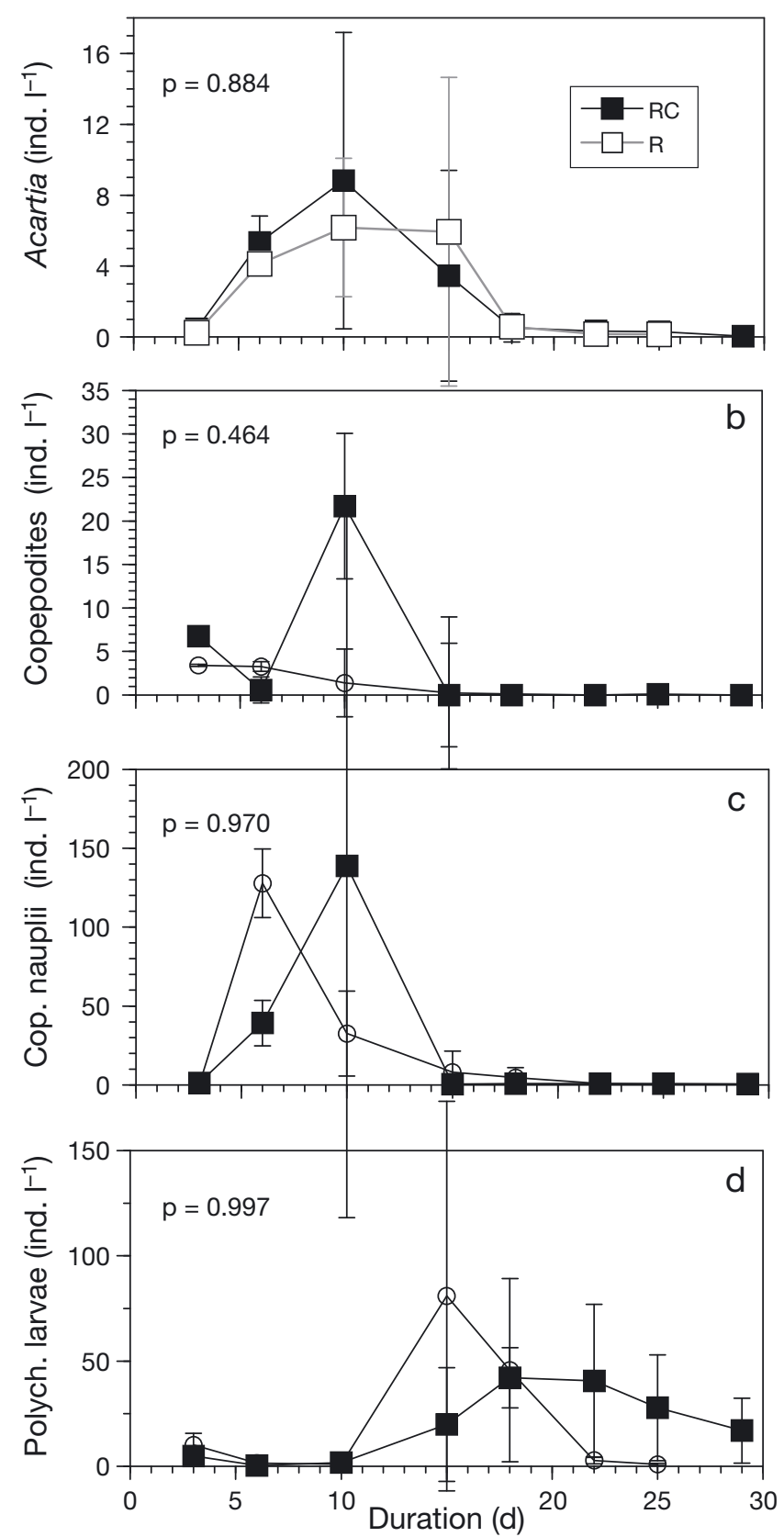

Fig. 11. Mesozooplankton abundance over the experiment: (a) adult Acartia sp., (b) copepodites, (c) copepod nauplii, and (d) polychaete larvae. Mean $\pm \mathrm{SD}, \mathrm{n}=3$. Statistical results indicated with $p$-value, statistical significance $p<0.05$ stages (Adey \& Loveland 1998) during the initial raw water fill of the tanks, and it took $\sim 1$ to $2 \mathrm{wk}$ until adult copepods and polychaete larvae were found (Fig. 11). The $\mathrm{R}$ tanks contained $\sim 7$ adult Acartia sp. $\mathrm{l}^{-1}$ in the middle of the experiment, while the $\mathrm{RC}$ tanks contained 8 adult Acartia sp. $\mathrm{l}^{-1}$. After 3 wk, Acartia sp. abundance decreased in all systems; however, polychaete larvae became abundant. About 25 to 40 polychaete larvae $\mathrm{l}^{-1}$ were found in the $\mathrm{R}$ tanks over the last 2 wk of the experiment (Fig. 11d), whereas after a phase of high abundance of polychaete larvae (75 ind. $\mathrm{l}^{-1}$ ) in the RC tanks, the numbers decreased (Fig. 11d). Acartia sp., copepodite, copepod nauplii, and polychaete abundances were not significantly different between systems (Fig. 11). Linear regression analysis showed no significant relation between phytoplankton biomass and zooplankton biomass (both converted to carbon units), and thus, it was the hard clams that affected phytoplankton biomass.

\section{DISCUSSION}

Direct and indirect interactions between hard clams and high bottom shear stress affected phytoplankton biomass, TSS concentrations, light availability, microphytobenthos biomass, and nutrient dynamics (Fig. 12). In the following text, we discuss the findings in relation to the original hypotheses posed.

Hypothesis 1 that hard clams decrease phytoplankton abundance and affect phytoplankton diversity despite high total suspended solid concentrations has to be accepted. Mercenaria mercenaria feeding significantly decreased phytoplankton biomass. The R tanks developed a phytoplankton bloom, whereas the RC tanks did not, except for a small bloom of brown tide algae Aureococcus anophagefferens in 2 of the 3 tanks. A type I brown tide of A. anophagefferens bloom is not, however, expected to affect bivalve activity. Research examining the interaction of hard clams and A. anophagefferens generally finds that much higher cell densities are required to affect hard clam growth and activity (Bricelj \& Lonsdale 1997, Wazniak \& Glibert 2004). Cerrato et al. (2004) found that $M$. mercenaria prevented the formation of blooms of $A$. anophagefferens. Phytoplankton composition was shifted toward Chlorophyceae/ Prasinophyceae in the RC tanks. M. mercenaria likely became food-limited during the experiments, as indicated by low phytoplankton biomass (Kemp et al. 2009) in the RC tanks. M. mercenaria selectively fed on phytoplankton and reduced phytoplankton concentrations in the RC tanks even though TSS lev- 

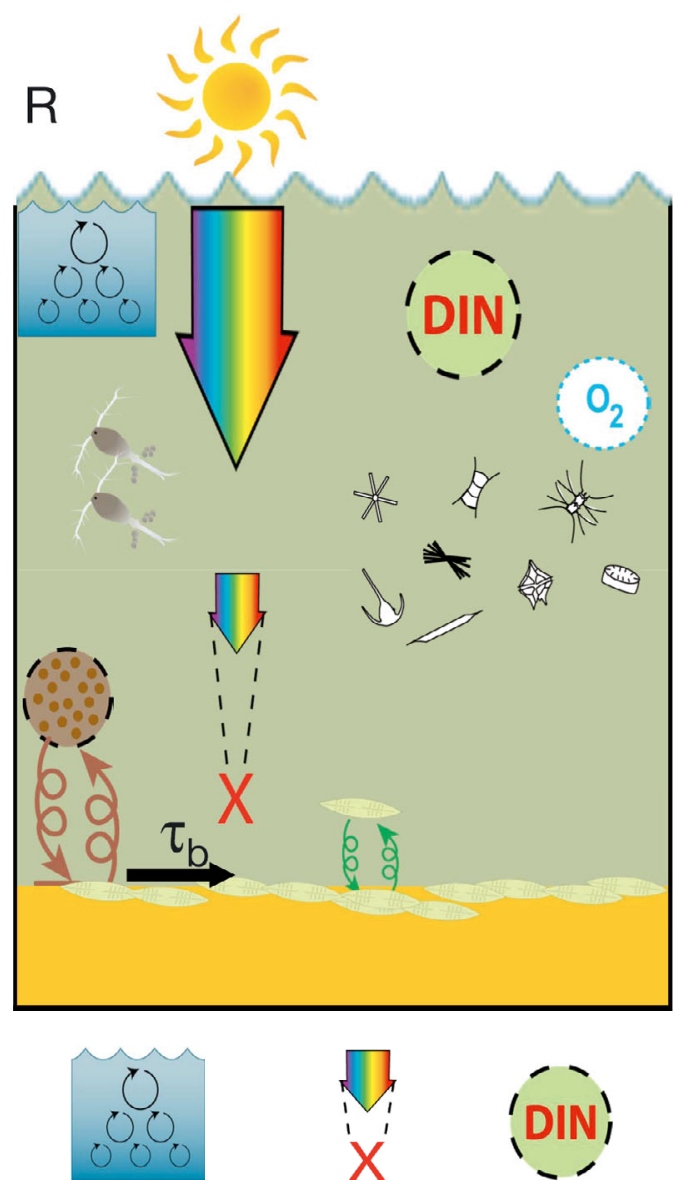

Turbulence intensity

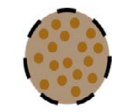

Total suspended solids

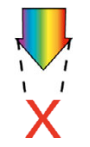

Light penetration

Resuspension

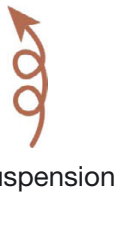

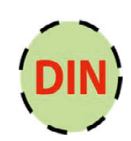

Nutrients

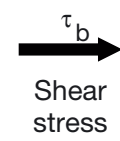

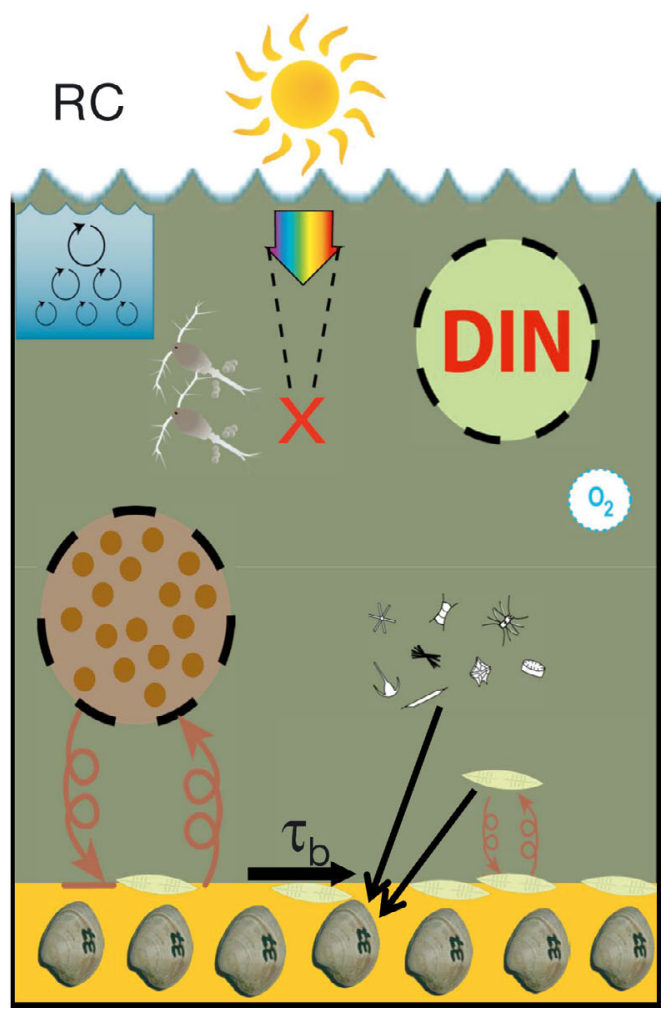

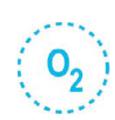

Dissolved oxygen

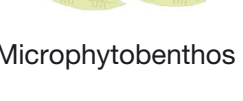

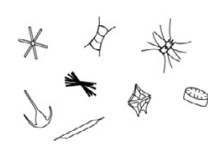

Zooplankton

Phytoplankton

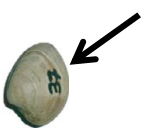

Phytoplankton and microphytobenthos uptake by clams

Fig. 12. Synthesis of experimental results comparing systems with tidal resuspension (R) and tidal resuspension with 50 hard clams (RC). Symbol size according to quantity or concentration. See 'Discussion'

els were as high as $200 \mathrm{mg} \mathrm{l}^{-1}$. In previous feeding studies, $M$. mercenaria had been found to not feed at

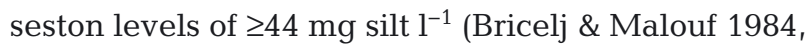
Bricelj et al. 1984). In a mesocosm experiment with tidal resuspension and different densities of hard clams the following year, valve gape measurements on individual clams suspended in cages at mid-water column height showed that clams were gaping $59 \pm$ $37 \%$ and $60 \pm 37 \%$ of the time (mean $\pm \mathrm{SD}, \mathrm{n}=15$, unpubl. data) during mixing 'on' and 'off' phases, respectively. Hard clams controlled phytoplankton biomass, as shown for other bivalves (Cloern 1982, Officer et al. 1982, Porter et al. 2004b); however, $M$. mercenaria did not control pelagic biomass in nonresuspension experiments by Doering et al. (1986). Copepod abundance was not decreased by $M$. mercenaria unlike the pattern found by Lonsdale et al. (2007).

Hypothesis 2 that a high density of hard clams in combination with high shear stress does not affect the nitrogen dynamics has to be rejected. Resuspended sediments, resuspended biodeposits, and bivalve excretion contributed to the higher nutrient levels in the RC tanks. Hard clams and tidal resuspension significantly affected nitrogen partitioning within the system, and the nitrogen budget differed 
between the $\mathrm{R}$ and the RC tanks. The R and RC systems accumulated similar amounts of N, with 59.4 vs. $57.9 \mathrm{mmol} \mathrm{N}$, respectively. In the RC tanks, dissolved nutrients dominated the system with a TDN of $62.8 \%$ of the nitrogen in the tank due to resuspension and from bivalve excretion. In the R tanks, TDN was still dominant but accounted for only $41 \%$ of the $\mathrm{N}$ budget. In addition, $32.5 \%$ and $24.9 \%$ of the $\mathrm{N}$ was associated with the microphytobenthos and phytoplankton, respectively, in the $\mathrm{R}$ tanks. In contrast, only $17 \%$ and $7.6 \%$ of $\mathrm{N}$ was microphytobenthos and phytoplankton, respectively, in the RC tanks. The lower values likely reflect the feeding on phytoplankton and microphytobenthos by the clams.

An excretion experiment of hard clams after an identical setup of 50 hard clams $\mathrm{m}^{-2}$ and a monthlong experiment with tidal resuspension in the following year showed that hard clams excreted $\sim 3.31 \pm$ $1.7 \mu$ moles $\mathrm{l}^{-1} \mathrm{~h}^{-1}$ DIN per individual (data not shown). Scaled up to tank level, bivalve excretion added 165.5 umoles DIN per tank per 50 hard clams $\mathrm{l}^{-1} \mathrm{~h}^{-1}$ or $3972 \mu$ moles DIN tank ${ }^{-1} \mathrm{~d}^{-1}$. Sma \& Baggaley (1976) also found a high rate of excretion in Mercenaria mercenaria. In the nitrogen budget, DIN in the RC tanks was $18.1 \%$ of the overall $\mathrm{N}$ budget, whereas it was only $4.9 \%$ in the R tanks. Decomposition of biodeposits may have taken place in the water column as biodeposits were resuspended, and this could be an additional nutrient source. Comparing these numbers to the average DIN content per RC tank (10320 $\pm 1080 \mu$ moles), the contribution of excretion to nutrient concentrations is large, but release from resuspended sediment particles was likely another important source of nutrients.

A major $\mathrm{N}$ input was due to daily water exchanges with $\mathrm{N}$ in the fill water, which were identical between the R and the RC tanks. Another major input was expected from benthic DIN fluxes of $\sim 2000 \mu \mathrm{mol}$ $\operatorname{tank}^{-1} \mathrm{~d}^{-1}$ in $\mathrm{R}$ systems, as measured in the $\mathrm{R}$ tanks the previous year (Porter et al. 2010). Effluxes are expected to be similar in the $\mathrm{RC}$ tanks as biodeposits were resuspended. However, some phytoplankton $\mathrm{N}$ was exported during the daily exchange in the $\mathrm{R}$ and RC tanks. We used estimates of porewater $\mathrm{N}$ release due to resuspension for the $\mathrm{R}$ tanks of $490 \mu \mathrm{mol} \mathrm{m} \mathrm{m}^{-2}$ $\mathrm{d}^{-1}$ from Porter et al. (2010) and scaled these up to the RC tanks, using the TSS concentrations. While porewater resuspension is slightly enhanced in the RC tanks, in both systems, it is at most a small additional source of N. In sandy sediments, stirring can induce additional porewater release due to advective flushing (Huettel \& Gust 1992), but this is not the case with the muddy sediments used in this experiment.
Hypothesis 3 that hard clams and high bottom shear stress decrease microphytobenthos abundance due to both feeding and light limitation has to be accepted. Mercenaria mercenaria feeding significantly decreased microphytobenthos biomass, as has also been found for other bivalve species (Sauriau \& Kang 2000, Rossi et al. 2004, Evrard et al. 2012). Microphytobenthos biomass was low in the RC tanks, which had reduced light penetration. During the last $9 \mathrm{~d}$ of the experiment, light levels were higher in the RC tanks with hard clams, yet overall microphytobenthos abundance was lower in the systems with hard clams, which suggests that bivalves were feeding on the microphytobenthos as it was resuspended (Fig. 12). Microphytobenthos is known to decrease nutrient regeneration (Sundbäck et al. 2000); thus, a reduction of microphytobenthos likely increased nutrient regeneration.

Fifty clams and high bottom shear stress initially destabilized the sediments in the RC tanks and reduced light penetration (Figs. 4, 9a,b, \& 12). Willows et al. (1998) also observed sediment destabilization with high densities of Macoma balthica in an annular flume set to stepwise increasing levels of bottom shear stress. Ciutat et al. $(2006,2007)$ found that different densities of cockles destabilized the sediments, whereas Andersen et al. (2010) did not find destabilization by cockles. We directly observed bioresuspension by a hard clam 'puffing' materials up into the water, using a webcam in an underwater housing. In addition, the burying behavior of Mercenaria mercenaria could have led to the sediment destabilization. Adult hard clams burrow with a muscular foot. Adult hard clams moved laterally $5 \mathrm{~cm}$ in $38 \mathrm{~d}$; however, juvenile hard clams 20 to $30 \mathrm{~mm}$ long moved $15 \mathrm{~cm}$ from the point of origin in an experiment by Chestnut (1951) as cited by Stanley (1985), which suggests a high potential for sediment destabilization. In our experiments, bivalves dug holes but seemed to stay within these holes with possible up and down movement. In a subsequent ecosystem experiment with different densities of $M$. mercenaria (unpubl. data), we observed similar effects of sediment destabilization at this hard clam density. Erosion studies in a $40 \mathrm{~cm}$ Gust microcosm (Gust \& Müller 1997), with different densities of hard clams added to the sediment $6 \mathrm{~d}$ before stepwise increases in erosion, showed similar sediment destabilization at a hard clam density of 5 ind. per $100 \mathrm{~cm}^{2}$ (Combs 2010). It has been shown that an enhanced water content can lead to sediment destabilization (de Deckere et al. 2001); however, the sediment water content in sediment cores from all 
tanks was similar between treatments and over the experiment.

Sediment preparation techniques (Treatment HD$\mathrm{m}$ in Porter et al. 2006) assured that sediments had stabilized geochemically at the start of the experiment, after 2 wk of consolidation time. Sediments in all tanks were prepared identically, and our defaunation technique did not lead to sediment destabilization.

The decrease in TSS concentrations in the RC tanks over the experiment suggests either that the burying behavior of the bivalves decreased during the experiment, that bivalves actively cleared the water column, or that the bed properties of the RC tanks changed, perhaps due to settled biodeposits by the clams. Microphytobenthos can stabilize sediments (Yallop et al. 1994), and significantly higher amounts of microphytobenthos biomass in the $\mathrm{R}$ tanks could have led to an enhanced sediment stabilization in the $\mathrm{R}$ tanks, thereby reducing resuspended TSS levels. Zimmerman \& de Szalay (2007) found that streambeds were destabilized when mussels were burrowing, but sediments were stabilized when mussels were not burrowing. Similar to our experiments, they found that sediments destabilized the first week after adding bivalves and stabilized thereafter. While many experiments have found initial destabilization after experiments are started with infauna and sediments (e.g. Willows et al. 1998, Ciutat et al. 2006, 2007, Widdows et al. 2009), most experiments are short term. It is possible that hard clams respond in their burying behavior to the initial change in bottom shear stress that they are exposed to and subsequently become accustomed to the high shear stress levels. If this is an artifact, the short-term studies have to be revised. The precise reason(s) for the decreasing TSS concentrations in the RC tanks remain unknown.

Mercenaria mercenaria feeding, burrowing, and biodeposition activities did not significantly change the properties of suspended particles as measured by their settling behavior and particle size distributions during settling. The suspended particle population appeared to be separated into 2 sub-populations: one that settled rapidly after mixing was turned off, with a bulk settling velocity of $\sim 1 \mathrm{~mm} \mathrm{~s}^{-1}$, and one that stayed suspended for the remainder of the mixing 'off' phase. This settling behavior is very similar to that observed after tidal resuspension in Chesapeake Bay (e.g. Sanford \& Halka 1993). Increases in particle size due to flocculation during initial settling accelerated the settling process. Overall, sediment destabilization due to the interaction of hard clams and high bottom shear stress greatly affected light penetration and the nutrient and oxygen dynamics (Fig. 12). High TSS concentrations increased the PN, PP, and PC concentrations. Dissolved inorganic nutrient concentrations were significantly higher in the RC tanks. In contrast, the dissolved inorganic nutrients were used by phytoplankton in the R tanks and lead to a phytoplankton bloom. DON concentrations were significantly higher in the RC tanks, and a combination of dissolved inorganic and organic nutrients available under low light conditions (Pustizzi et al. 2004) could have led to the small Aureococcus anophagefferens bloom in 2 of the RC tanks on Day 17.

Field studies have shown that dense populations of bivalve filter feeders can significantly affect benthicpelagic coupling processes, including the transfer of materials to the bottom (Asmus et al. 1992, Norkko et al. 2001) and nutrient regeneration from the sediments (Dame et al. 1985, Doering et al. 1987, Porter et al. 2004b). Mercenaria mercenaria controlled phytoplankton biomass, as shown for other bivalve suspension-feeders (Cloern 1982, Officer et al. 1982, Porter et al. 2004b), while hard clams did not control pelagic biomass in a mesocosm experiment by Doering et al. (1986). Typical mesocosm studies have unrealistically low bottom shear stress (Porter et al. 2004a) so that resuspension cannot be mimicked. In the field, however, bottom shear stress is enhanced and can lead to TSS levels ranging from $40 \mathrm{mg} \mathrm{l}^{-1}$ (Sanford et al. 1991) to hundreds of $\mathrm{mg} \mathrm{l}^{-1}$ (Schoellhamer 1995, 2002, Heyes et al. 2004).

Mercenaria mercenaria is now being farmed on a large scale in the high-salinity Virginia portion of the Chesapeake Bay ('aqua farming', M. Luckenbach, Virginia Institute of Marine Science, pers. comm.). Filtering by hard clams, even if there is resuspension, should decrease phytoplankton abundance at these farms. Densely planted hard clams in interaction with changing bottom shear stress during tidal cycles or resuspension during harvesting activity may, however, adversely affect TSS levels. Nutrient regeneration from resuspension and bivalve excretion may adversely affect the nitrogen dynamics. The balance of positive and negative ecosystem effects of hard clam aquaculture have to be weighed.

Overall, a high density of hard clams and high bottom shear stress affected phytoplankton abundance, microphytobenthos biomass, TSS concentrations, and the nitrogen dynamics in these experiments. The interplay of bottom shear stress and a dense assemblage of infaunal bivalve suspension feeders significantly affected benthic-pelagic coupling processes. 
Acknowledgements. We thank M. Reardon, H. Soulen, E. H. Kim, and C. Bergeron for their help with this experiment and $\mathrm{H}$. Soulen for processing the zooplankton samples. Moreover, we thank the CBL and HPL Analytical Services Departments for analyzing many samples and the Chesapeake Biological Laboratory, University of Maryland Center for Environmental Science (UMCES), for providing space to set up the mesocosm facility. The pigments were quantified by L. Van Heukelem and C. Thomas at the Analytical Services Department at the Horn Point Laboratory at the University of Maryland Center for Environmental Science in Cambridge, MD, but the data were not interpreted. Cherrystone Aqua Farms kindly provided the hard clams. The crew of the RV 'Aquarius' helped us collect the sediments. The symbols are courtesy of the Integration and Application Network (http://ian.umces.edu/symbols/). We thank three anonymous reviewers for their detailed reviews and constructive criticisms that improved the manuscript. Our research was supported by grant R 824850-01-0 from the USEPA STAR program as part of the Multiscale Experimental Ecosystem Research Center (MEERC) at UMCES and by grant 35236 by the Hudson River Foundation to R.P.M., E.T.P., and L.P.S. E.T.P. thanks Washington College for a faculty enhancement grant. This is a publication of Washington College and contribution number 4744 of UMCES.

\section{LITERATURE CITED}

Aberle J, Nikora V, Walters R (2004) Effects of bed material properties on cohesive sediment erosion. Mar Geol 207: 83-93

Adey WH, Loveland K (1998) Pumps. In: Adey WH, Loveland $\mathrm{K}$ (eds) Dynamic aquaria. Building living ecosystems. Academic Press, San Diego, CA, p 27-33

Agrawal YC, Pottsmith HC (2004) LISST laser diffraction sensors advance sediment monitoring: laser system also measures water's inherent optical properties and volume scattering function. Sea Technol 45:33-38

- Andersen TJ, Lanuru M, van Bernem C, Pejrup M, Riethmueller R (2010) Erodibility of a mixed mudflat dominated by microphytobenthos and Cerastoderma edule, East Frisian Wadden Sea, Germany. Estuar Coast Shelf Sci 87:197-206

- Asmus H, Asmus RM, Prins TC, Dankers N, Francés G, Maaß B, Reise K (1992) Benthic-pelagic flux rates on mussel beds: tunnel and tidal flume methodology compared. Helgol Meersunters 46:341-361

Baker JE, Mason RP, Cornwell JC, Ashley J, Halka J, Hill J (1997) Spatial mapping of sedimentary contaminants in the Baltimore Harbor/Patapsco River/Back River system. Final report to the Maryland Department of the Environment. University of Maryland Center for Environmental Science/Chesapeake Biological Laboratory, Solomons, MD, p 97-142

Berg JA, Newell RIE (1986) Temporal and spatial variations in the composition of seston available to the suspension feeder Crassostrea virginica. Estuar Coast Shelf Sci 23: 375-386

Blanchard GF, Sauriau PG, Cariou-Le Gall V, Gouleau D, Garet MJ, Olivier F (1997) Kinetics of tidal resuspension of microbiota: testing the effects of bioturbation using flume experiments. Mar Ecol Prog Ser 151:17-25

Bricelj MV, Lonsdale DJ (1997) Aureococcus anophagefferens: causes and ecological consequences of brown tides in U.S. mid-Atlantic coastal waters. Limnol Oceanogr 42: 1023-1038

- Bricelj VM, Malouf RE (1984) Influence of algal and suspended sediment concentrations on the feeding physiology of the hard clam Mercenaria mercenaria. Mar Biol 84:155-165

> Bricelj VM, Malouf RE, deQuillfeldt C (1984) Growth of juvenile Mercenaria mercenaria and the effect of resuspended bottom sediments. Mar Biol 84:167-173

> Cerrato RM, Caron DA, Lonsdale DJ, Rose JM, Schaffner RA (2004) Effect of the northern quahog Mercenaria mercenaria on the development of blooms of the brown tide alga Aureococcus anophagefferens. Mar Ecol Prog Ser 281:93-108

> Chen CC, Petersen JE, Kemp WM (1997) Spatial and temporal scaling of periphyton growth on walls of estuarine mesocosms. Mar Ecol Prog Ser 155:1-15

Chestnut AF (1951) The oyster and other mollusks in North Carolina. In: Taylor HF (ed) Survey of marine fisheries of North Carolina. University of North Carolina Press, Chapel Hill, NC, p 141-190

> Ciutat A, Widdows J, Readman JW (2006) Influence of cockle Cerastoderma edule bioturbation and tidal-current cycles on resuspension of sediment and polycyclic aromatic hydrocarbons. Mar Ecol Prog Ser 328:51-64

Ciutat A, Widdows J, Pope ND (2007) Effect of Cerastoderma edule density on near-bed hydrodynamics and stability of cohesive muddy sediments. J Exp Mar Biol Ecol 346:114-126

Cloern JE (1982) Does the benthos control phytoplankton biomass in South San Francisco Bay? Mar Ecol Prog Ser 9:191-202

Combs EA (2010) The effects of the interaction of the bivalve, Mercenaria mercenaria, and bottom shear stress on total suspended solid concentrations. Senior Capstone Experience thesis. Washington College, Chestertown, $\mathrm{MD}$

> Dame RF, Wolaver TG, Libes SM (1985) The summer uptake and release of nitrogen by an intertidal oyster reef. Neth J Sea Res 19:265-268

> Davis WR (1993) The role of bioturbation in sediment resuspension and its interaction with physical shearing. J Exp Mar Biol Ecol 171:187-200

de Deckere E, Tolhurst TJ, de Brouwer JFC (2001) Destabilization of cohesive intertidal sediments by infauna. Estuar Coast Shelf Sci 53:665-669

> de Jonge VN (1980) Fluctuations in the organic carbon to chlorophyll a ratios for estuarine benthic diatom populations. Mar Ecol Prog Ser 2:345-353

Diplas P, Dancey CL, Celik AO, Valyrakis M, Greer K, Akar $\mathrm{T}$ (2008) The role of impulse on the initiation of particle movement under turbulent flow conditions. Science 322: 717-720

Doering PH, Oviatt CA, Kelly JF (1986) The effects of the filter feeding clam Mercenaria mercenaria on carbon cycling in experimental mesocosms. J Mar Res 44: 839-861

> Doering PH, Kelly JR, Oviatt CA, Sowers T (1987) Effect of the hard clam Mercenaria-mercenaria on benthic fluxes of inorganic nutrients and gases. Mar Biol 94:377-383

- Evrard V, Huettel M, Cook PLM, Soetaert K, Heip CHR, Middelburg JJ (2012) Importance of phytodetritus and microphytobenthos for heterotrophs in a shallow subtidal sandy sediment. Mar Ecol Prog Ser 455:13-31

Fegley SR, MacDonald BA, Jacobsen TR (1992) Short-term 
variation in the quantity and quality of seston available to benthic suspension feeders. Estuar Coast Shelf Sci 34: 393-412

Fisher TR, Peele ER, Ammerman JW, Harding LW Jr (1992) Nutrient limitation of phytoplankton in Chesapeake Bay. Mar Ecol Prog Ser 82:51-63

Fisher TR, Gustafson AB, Sellner K, Lacouture R and others (1999) Spatial and temporal variation of resource limitation in Chesapeake Bay. Mar Biol 133:763-778

> Frithsen JB, Rudnick DT, Doering PH (1986) The determination of fresh organic carbon weight from formaldehyde preserved macrofaunal samples. Hydrobiologia 133: 203-208

Gust G (1988) Skin friction probes for field applications. J Geophys Res 93:14,121-14,132

Gust G, Müller V (1997) Interfacial hydrodynamics and entrainment functions of currently used erosion devices. In: Burt N, Parker R, Watts J (eds) Cohesive sediments. John Wiley \& Sons, Chichester, NY, p 149-174

$>$ Harding LW, Mallonee ME, Perry ES (2002) Toward a predictive understanding of primary productivity in a temperate, partially stratified estuary. Estuar Coast Shelf Sci 55:437-463

Herman PMJ, Middelburg JJ, Widdows J, Lucas CH, Heip CHR (2000) Stable isotopes as trophic tracers: combining field sampling and manipulative labeling of food resources for macrobenthos. Mar Ecol Prog Ser 204: 79-92

- Heyes A, Miller C, Mason RP (2004) Mercury and methylmercury in Hudson River sediment: impact of tidal resuspension on partitioning and methylation. Mar Chem 90: 75-89

> Huettel M, Gust G (1992) Solute release mechanisms from confined sediment cores in stirred benthic chambers and flume flows. Mar Ecol Prog Ser 82:187-197

Jeffrey SW, Vesk M (1997) Introduction to marine phytoplankton and their pigment signatures. In: Jeffrey SW, Mantoura RFC, Wright SW (eds) Phytoplankton pigments in oceanography: guidelines to modern methods, Vol 10. Monographs on oceanographic methodology. UNESCO Publishing, Paris, p 74-75, Table 2.3

Karakassis I, Tsapakis M, Hatziyanni E (1998) Seasonal variability in sediment profiles beneath fish farm cages in the Mediterranean. Mar Ecol Prog Ser 162:243-252

Keefe CW, Blodnikar KL, Boynton WR, Clark CA and others (2004) Nutrient analytical services laboratory standard operating procedures. Spec Pub Ser No. SS-80-04-CBL. Chesapeake Biological Laboratory, University of Maryland Center for Environmental Science, Solomons, MD, available at http://archive.chesapeakebay.net/pubs/ quality_assurance/CBL_NASL_SOP_Feb_2004.pdf (accessed 19 November 2012)

Kemp WM, Petersen SE, Houde ED, Chen CC, Cornwell JC, Porter ET (2009) Spatial and temporal scaling. In: Petersen JE, Kennedy VS, Dennison WC, Kemp WM (eds) Enclosed experimental ecosystems and scale: tools for understanding and managing coastal ecosystems. Springer, New York, NY, p 49-62

> Lonsdale DJ, Cerrato RM, Caron DA, Schaffner RA (2007) Zooplankton changes associated with grazing pressure of northern quahogs (Mercenaria mercenaria L.) in experimental mesocosms. Estuar Coast Shelf Sci 73: 101-110

MacIntyre HL, Geider RJ, Miller DC (1996) Microphytobenthos: the ecological role of the 'secret garden' of unvegetated, shallow-water marine habitats. I. Distribution, abundance and primary production. Estuaries 19: 186-201

Marshall HG (1994) Chesapeake Bay phytoplankton: I. Composition. Proc Biol Soc Wash 107:573-585

Marshall HG, Burchardt L, Lacouture R (2005) A review of phytoplankton composition within Chesapeake Bay and its tidal estuaries. J Plankton Res 27:1083-1102

Mason RP, Porter ET (2009) Toxicity and bioaccumulation in benthic organisms. In: Petersen JE, Kennedy VS, Dennison DC, Kemp WM (eds) Enclosed experimental ecosystems and scale: tools for understanding and managing coastal ecosystems. Springer, New York, NY, p 203-211

Meadows PS, Tait J (1989) Modification of sediment permeability and shear strength by two burrowing invertebrates. Mar Biol 101:75-82

> Murphy RC, Kremer JN (1985) Bivalve contribution to benthic metabolism in a California lagoon. Estuaries 8: 330-341

> Muschenheim DK, Newell CR (1992) Utilization of seston flux over a mussel bed. Mar Ecol Prog Ser 85:131-136

> Norkko A, Hewitt JE, Thrush SF, Funnell GA (2001) Benthic-pelagic coupling and suspension-feeding bivalves: linking site-specific sediment flux and biodeposition to benthic community structure. Limnol Oceanogr 46: 2067-2072

> Officer CB, Smayda TJ, Mann R (1982) Benthic filter feeding: a natural eutrophication control. Mar Ecol Prog Ser 9:203-210

Parsons TR, Maita Y, Lalli CM (1984) A manual of chemical and biological methods for seawater analysis. Pergamon, Oxford University Press, Oxford

> Petersen JE, Sanford LP, Kemp WM (1998) Coastal plankton responses to turbulent mixing in experimental ecosystems. Mar Ecol Prog Ser 171:23-41

> Porter ET, Sanford LP, Gust G, Porter FS (2004a) Combined water column mixing and benthic boundary-layer flow in mesocosms: key for realistic benthic-pelagic coupling studies. Mar Ecol Prog Ser 271:43-60

> Porter ET, Cornwell JC, Sanford LP, Newell RIE (2004b) Effect of oysters Crassostrea virginica and bottom shear velocity on benthic-pelagic coupling and estuarine water quality. Mar Ecol Prog Ser 271:61-75

Porter ET, Owens M, Cornwell JC (2006) Effect of sediment manipulation on the biogeochemistry of experimental sediment systems. J Coast Res 22:1539-1551

Porter ET, Mason RP, Sanford LP (2010) Effect of tidal resuspension on benthic-pelagic coupling in an experimental ecosystem study. Mar Ecol Prog Ser 413:33-53

> Prins TC, Smaal AC, Pouwer AJ, Dankers N (1996) Filtration and resuspension of particulate matter and phytoplankton on an intertidal mussel bed in the Oosterschelde estuary (SW Netherlands). Mar Ecol Prog Ser 142: 121-134

> Pustizzi F, MacIntyre H, Warner ME, Hutchins DA (2004) Interaction of nitrogen source and light intensity on the growth and photosynthesis of the brown tide alga Aureococcus anophagefferens. Harmful Algae 3:343-360

Reece JB, Urry LA, Cain ML, Wasserman SA, Minorsky PV, Jackson RB (2011) Campbell biology, 9th edn. Pearson Benjamin Cummings, San Francisco, CA

Rossi F, Herman PMJ, Middelburg JJ (2004) Interspecific and intraspecific variation of $\mathrm{d}^{13} \mathrm{C}$ and $\mathrm{d}^{15} \mathrm{~N}$ in depositand suspension-feeding bivalves (Macoma balthica and Cerastoderma edule): evidence of ontogenetic changes 
in feeding mode of Macoma balthica. Limnol Oceanogr 49:408-414

Saila SB, Flowers JM, Cannario MT (1966) Factors affecting the relative abundance of Mercenaria mercenaria in the Providence River, Rhode Island. Proc Natl Shellfish Assoc 57:83-89

Sanford LP (1997) Turbulent mixing in experimental ecosystem studies. Mar Ecol Prog Ser 161:265-293

Sanford LP, Suttles S, Porter ET (2009) Physical factors: mixing and flow. In: Petersen JE, Kennedy VS, Dennison WC, Kemp WM (eds) Enclosed experimental ecosystems and scale. Springer, New York, NY, p 63-74

Sanford LP, Halka JP (1993) Assessing the paradigm of mutually exclusive erosion and deposition of mud, with examples from upper Chesapeake Bay. Mar Geol 114: $37-57$

Sanford LP, Panageotou W, Halka JP (1991) Tidal resuspension of sediments in northern Chesapeake Bay. Mar Geol 97:87-103

Sauriau PG, Kang CK (2000) Stable isotope evidence of benthic microalgae-based growth and secondary production in the suspension feeder Cerastoderma edule (Mollusca, Bivalvia) in the Marennes-Oleron Bay. Hydrobiologia 440:317-329

Schneider AR, Porter ET, Baker JE (2007) Polychlorinated biphenyl release from resuspended Hudson River sediment. Environ Sci Technol 41:1097-1103

Schoellhamer DH (1995) Sediment resuspension mechanisms in Old Tampa Bay, Florida. Estuar Coast Shelf Sci 40:603-620

Schoellhamer DH (2002) Variability of suspended-sediment concentration at tidal to annual time scales in San Francisco Bay, USA. Cont Shelf Res 22:1857-1866

Sma RF, Baggaley A (1976) Rate of excretion of ammonia by the hard clam Mercenaria mercenaria and the American Oyster Crassostrea virginica. Mar Biol 36:251-258

Stanley JG (1985) Species profiles: life histories and environmental requirements of coastal fishes and invertebrates (mid-Atlantic) - Hard clam. US Fish Wildl Serv Biol Rep 82 (11.41), US Army Corps of Engineers, TR EL82-4, Washington, DC

Sundbäck, K, Miles A, Göransson E (2000) Nitrogen fluxes, denitrification and the role of microphytobenthos in microtidal shallow-water sediments: an annual study. Mar Ecol Prog Ser 200:59-76

Trice TM, Glibert PM, Lea C, Van Heukelem L (2004) HPLC pigment records provide evidence of past blooms of Aureococcus anophagefferens in the Coastal Bays of Maryland and Virginia, USA. Harmful Algae 3:295-304
Van Heukelem L, Thomas CS (2001) Computer-assisted high-performance liquid chromatography method development with applications to the isolation and analysis of phytoplankton pigments. J Chromatogr A 910:31-49

Van Heukelem L, Thomas CS (2005) The HPL method, Chap 5. In: Hooker SB, Van Heukelem L, Thomas CS, Claustre $\mathrm{H}$ and others (eds) The second SeaWiFs HPLC Analysis Round Robin Experiment (SeaHARRE-2). NASA/ TM-2005-212785, Washington, DC, p 88-89, Table 50, available at http://oceancolor.gsfc.nasa.gov/DOCS/SH2 _TM2005_212785.pdf (accessed 19 November 2012)

- Wazniak CE, Glibert PM (2004) Potential impacts of brown tide, Aureococcus anophagefferens, on juvenile hard clams, Mercenaria mercenaria, in the Coastal Bays of Maryland, USA. Harmful Algae 3:321-329

Welschmeyer NA (1994) Fluorometric analysis of chlorophyll $a$ in the presence of chlorophyll $b$ and phaeopigments. Limnol Oceanogr 39:1985-1992

White JR, Roman MR (1992) Seasonal study of grazing by metazoan zooplankton in the mesohaline Chesapeake Bay. Mar Ecol Prog Ser 86:251-261

> Widdows J, Brinsley MD, Pope ND (2009) Effect of Nereis diversicolor density on the erodability of estuarine sediment. Mar Ecol Prog Ser 378:135-143

- Willows RI, Widdows J, Wood RG (1998) Influence of an infaunal bivalve on the erosion of an intertidal cohesive sediment: a flume and modeling study. Limnol Oceanogr 43:1332-1343

Wright LD, Schaffner LC, Maa JPY (1997) Biological mediation of bottom boundary layer processes and sediment suspension in the lower Chesapeake Bay. Mar Geol 141: 27-50

> Yallop ML, De Winder B, Paterson DM, Stal LJ (1994) Comparative structure, primary production and biogenic stabilization of cohesive and non-cohesive marine sediments inhabited by microphytobenthos. Estuar Coast Shelf Sci 39:565-582

- Zimmerman GF, de Szalay FA (2007) Influence of unionid mussels (Mollusca: Unionidae) on sediment stability: an artificial stream study. Fund Appl Limnol 168: 299-306

Zimmermann CF, Keefe CW, Basche J (1997) EPA Method 440.0. Determination of carbon and nitrogen in sediments and particulates of estuarine/coastal waters using elemental analysis. National Exposure Research Laboratory, Office of Research and Development, US Environmental Protection Agency, Cincinnati, $\mathrm{OH}$, available at www.caslab.com/EPA-Methods/PDF/EPA-Method-440.pdf (accessed March 12, 2013) 


\section{Appendix 1}

\section{Analytical methods}

Chlorophyll a (chl a) concentrations were measured using fluorometric techniques without acidification (Welschmeyer 1994) after extraction with $90 \%$ acetone to provide estimates of phytoplankton biomass. Phaeophytin was measured following Keefe et al. (2004). To determine total suspended seston (TSS) mass, seston filters were reweighed on a Mettler AE 240 microbalance after drying for $24 \mathrm{~h}$ to constant weight at $60^{\circ} \mathrm{C}$. Then, the filters were ashed at $450^{\circ} \mathrm{C}$ for $4 \mathrm{~h}$ and re-weighed to determine particulate inorganic matter (PIM) concentrations. Particulate organic matter (POM) was determined by the difference between TSS and PIM (Berg \& Newell 1986).

Water samples were analyzed for particulate phosphorus (PP) following techniques described by Keefe et al. (2004). Particulate carbon (PC) and nitrogen (PN) samples were analyzed on an Exeter Analytical $(\mathrm{CHN})$ analyzer using Environmental Protection Agency method 440.0 (Zimmermann et al. 1997). Ammonium, nitrite plus nitrate, and phosphate were analyzed following the Technicon Industrial methods No. 804-86T, No. 158-71W, and No. 155-71W/Tentative, respectively, and total dissolved nitrogen (TDN) and phosphorus (TDP) were analyzed using methods described by Keefe et al. (2004). Dissolved organic phosphorus (DOP) was calculated by the difference between TDP and phosphate $\left(\mathrm{PO}_{4}{ }^{3-}\right)$. We calculated dissolved organic nitrogen (DON) levels based on the difference between TDN and dissolved inorganic nitrogen (DIN). We analyzed dissolved silicate using a Technicon TrAAcs-800 nutrient analyzer with oxalic acid added to minimize interference from phosphates. Particulate silicate was analyzed as described by Keefe et al. (2004), as was DOC. For all variables, for quality control, every sixth sample was analyzed in duplicate. Nutrients and watercolumn chl a were analyzed by the Analytical Services Laboratory of the Chesapeake Biological Laboratory, University of Maryland Center for Environmental Science (http://archive.chesapeakebay.net/pubs/quality_assurance/ CBL_NASL_SOP_Feb_2004.pdf). These were the same techniques as used by Porter et al. (2010).

We extracted sediment $\mathrm{chl}$ a by adding $20 \mathrm{ml}$ of $100 \%$ acetone to the sample tubes, sonicating each tube for 15 cycles at $0^{\circ} \mathrm{C}$, and letting the sample extract further in a freezer overnight. After decanting, an additional $20 \mathrm{ml}$ of $90 \%$ acetone was added, and the sample was again sonicated and left to extract for another $3 \mathrm{~h}$. The supernatant was decanted after centrifugation and subsequently analyzed by high performance liquid chromatography (HPLC; Van Heukelem \& Thomas 2001). HPLC was used to prevent interference from degradation products, such as chlorophyllides and pheophorbides, that interfere with fluorescence measurements (MacIntyre et al. 1996) and affect chl a readings. Chlorophyllides and pheophorbides can be abundant in areas with bivalves (e.g. Karakassis et al. 1998). In prior tests, we had found that this technique efficiently extracted $\sim 97 \%$ of the sediment chl a from sediments containing a range of sediment chl a concentrations. We pooled extracts from samples taken in 3 quadrants of each tank and analyzed triplicate samples for each treatment for sediment chl $a$ and phaeophytin. 
